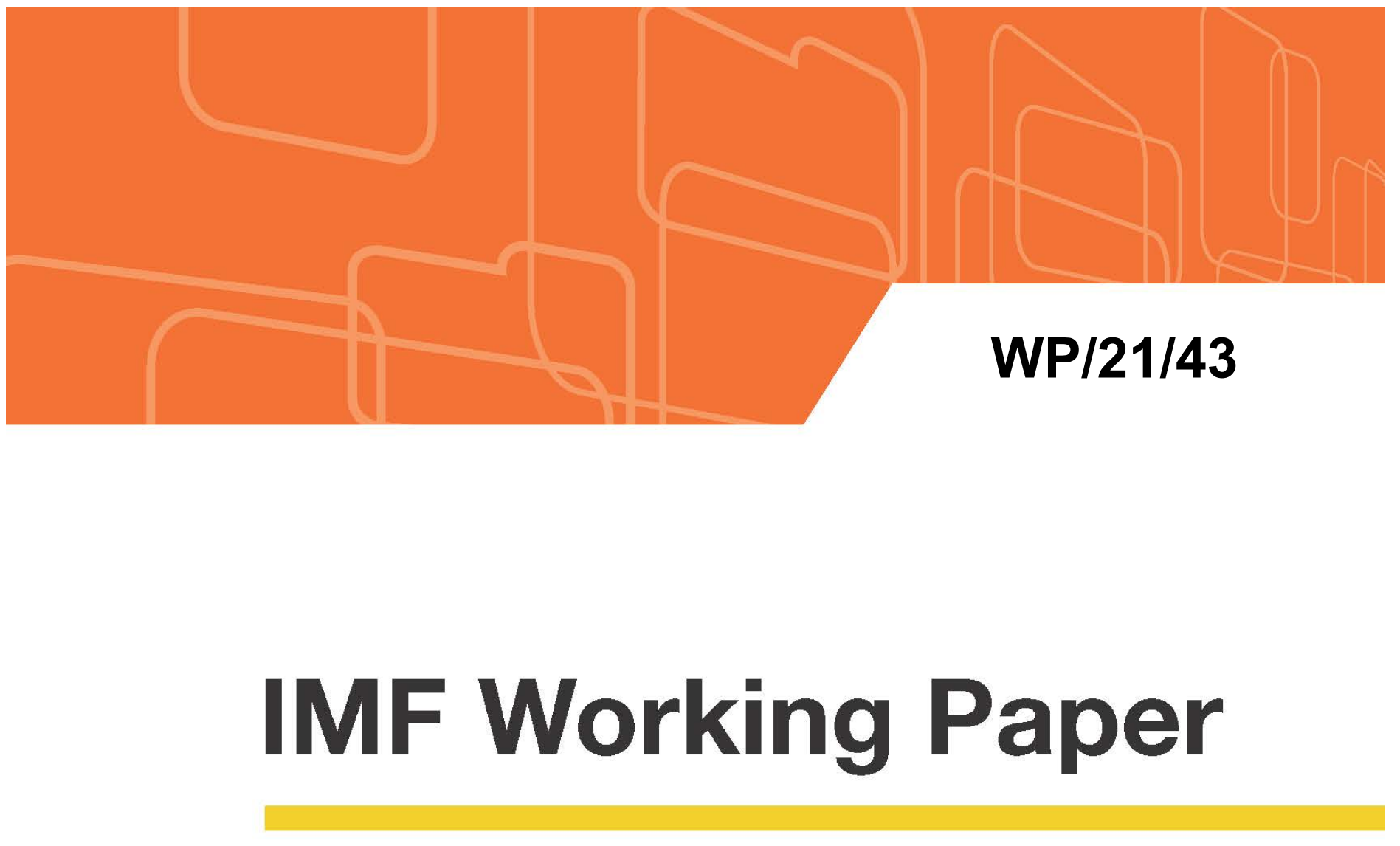

\title{
Credit Cycles, Fiscal Policy, and Global Imbalances
}

\author{
by Callum Jones and Pau Rabanal
}

IMF Working Papers describe research in progress by the author(s) and are published to elicit comments and to encourage debate. The views expressed in IMF Working Papers are those of the author(s) and do not necessarily represent the views of the IMF, its Executive Board, or IMF management.

$$
\text { I N T E R N A T I O }
$$




\title{
IMF Working Paper
}

Research Department

\section{Credit Cycles, Fiscal Policy, and Global Imbalances ${ }^{1}$ \\ Prepared by Callum Jones² and Pau Rabanal}

Authorized for distribution by Daniel Leigh

February 2021

IMF Working Papers describe research in progress by the author(s) and are published to elicit comments and to encourage debate. The views expressed in IMF Working Papers are those of the author(s) and do not necessarily represent the views of the IMF, its Executive Board, or IMF management.

\begin{abstract}
We study the role that changes in credit and fiscal positions play in explaining current account fluctuations. Empirically, the current account declines when credit increases, and when the fiscal balance declines. We use a two-country model with financial frictions and fiscal policy to study these facts. We estimate the model using annual data for the U.S. and "a rest of the world" aggregate that includes main advanced economies. We find that about 30 percent of U.S. current account balance fluctuations are due to domestic credit shocks, while fiscal shocks explain about 14 percent. We evaluate simple macroprudential policy rules and show that they help reduce global imbalances. By taming the financial cycle, macroprudential rules that react to domestic credit conditions or to domestic house prices would have led to a smaller and less volatile U.S. current account deficit. We also show that a countercylical fiscal policy rule that stabilizes output growth reduces the level and volatility of the U.S. current account deficit.

JEL Classification Numbers: C52, C54, F41.
\end{abstract}

Keywords: Current account balances, credit cycles, fiscal policy, macroprudential policies. Authors’ E-Mail Addresses: callum.j.jones@,frb.gov; prabanal@imf.org.

\footnotetext{
${ }^{1}$ We are thankful to Carlos Gonçalves and Daniel Leigh for useful comments and to Kyun Suk Chang for research assistance. The views expressed are those of the authors and not necessarily those of the Federal Reserve Board or the Federal Reserve System.

${ }^{2}$ Division of Monetary Affairs, Federal Reserve Board. Constitution Ave NW \& 20th St NW, Washington, DC 20551.
} 


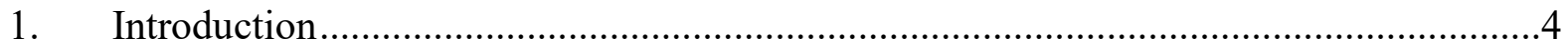

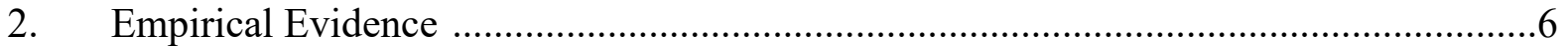

2.1. The Relationship between Credit and the Current Account ....................................... 7

2.2. The Relationship between the Fiscal Balance and the Current Account ......................10

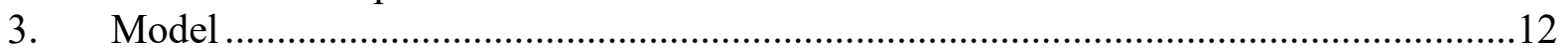

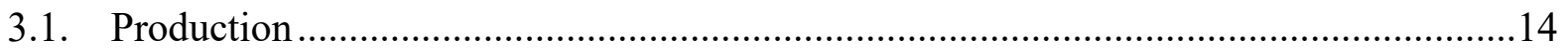

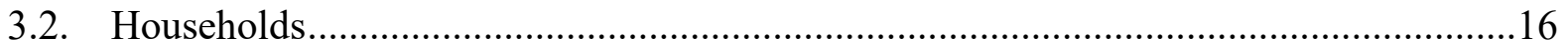

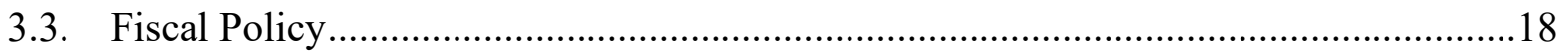

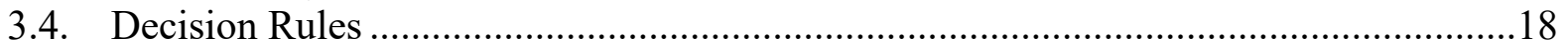

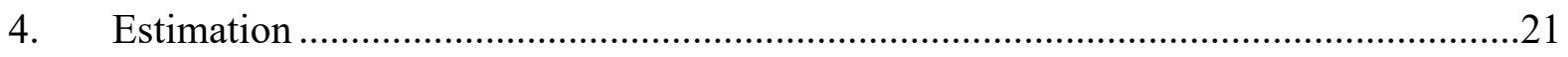

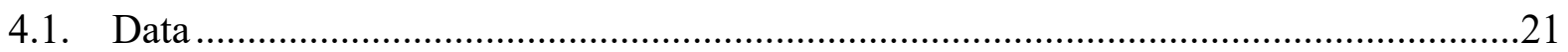

4.2. GMM Estimation and Parameter Estimates..............................................................22

4.3. Model Implications: Impulse-Responses and Model Fit ...........................................25

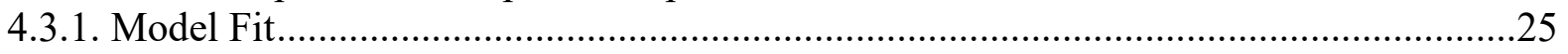

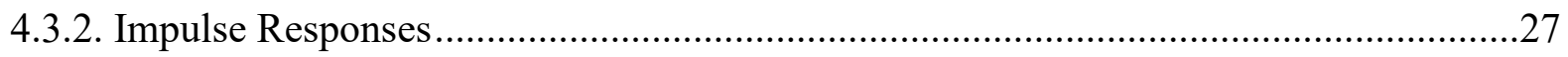

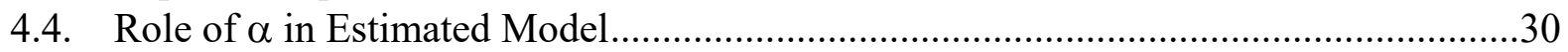

5. Credit Shocks, Fiscal Policy, and the Current Account.............................................30

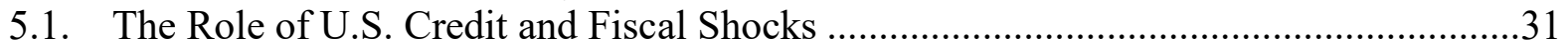

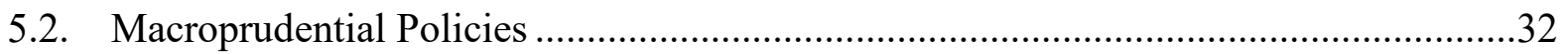

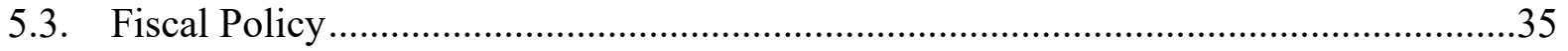

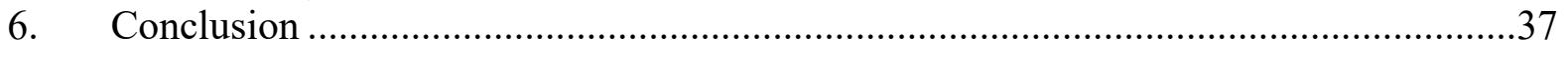

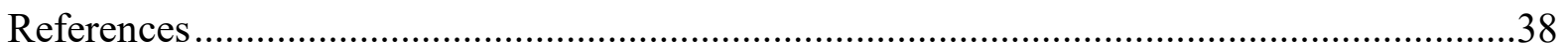

Tables

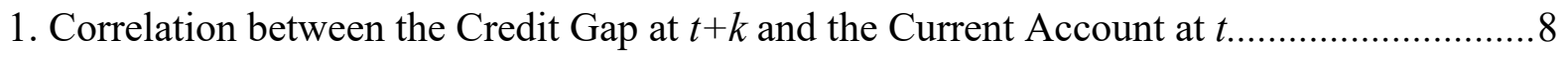

2. Correlation between the Fiscal Balance at $t+k$ and the Current Account at $t \ldots \ldots \ldots \ldots \ldots \ldots \ldots . . . . . .11$

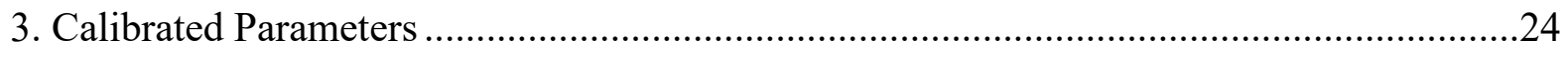

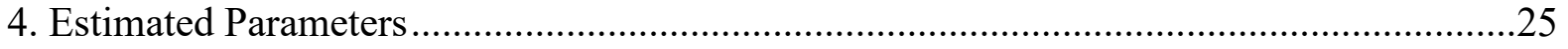

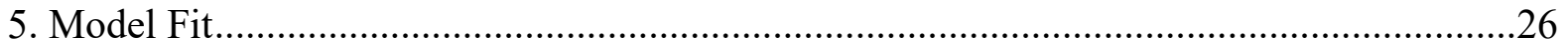

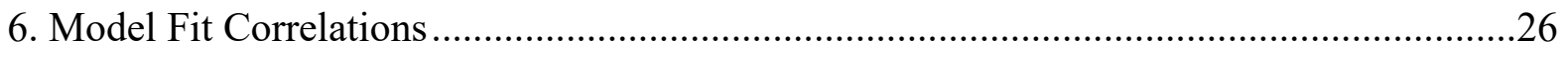

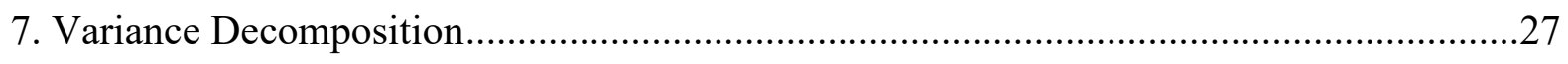

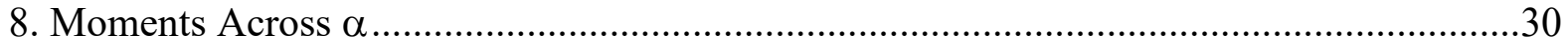

Figures

1. Correlation between the Credit Gap and the Current Account ........................................9

2. Correlation between the Fiscal Balance and the Current Account ...................................12

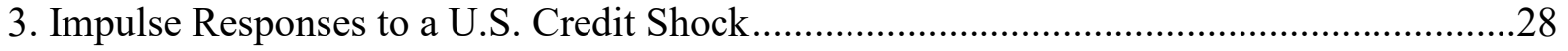

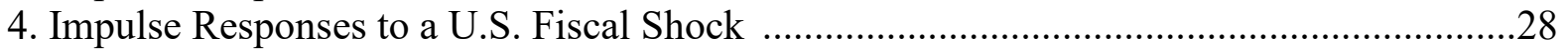

5. Impulse Responses to a U.S. Productivity Shock ...........................................................29

6. U.S. Current Account to GDP, Counterfactuals ........................................................... 31

7. Macroprudential Rule Responding to Household Credit Shocks ....................................34

8. Macroprudential Rule Responding to Household Price Fluctuations .................................34

9. Fiscal Rule Responding to Lagged Output Growth ...................................................36 
Appendix .41

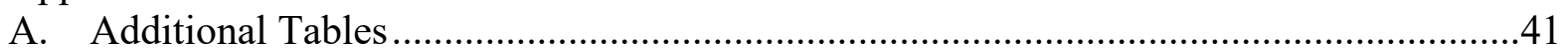

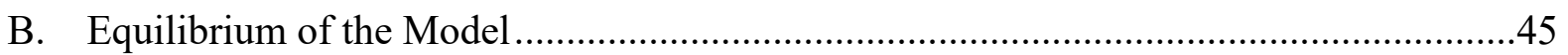

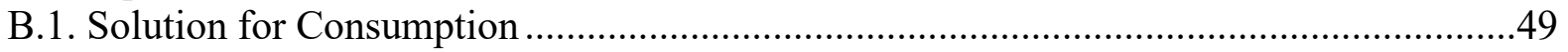

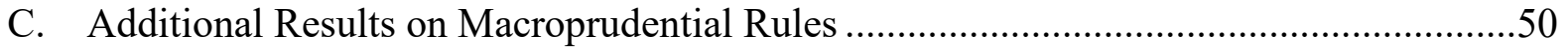

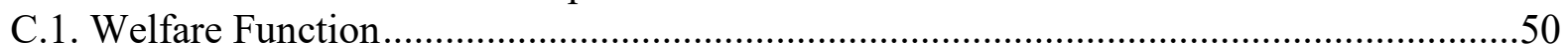

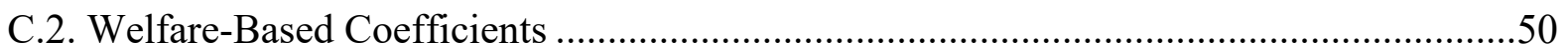

C.3. Macropru Rule Targeting House Prices at Optimal Coefficients ....................................51

Appendix Tables

A.1. Correlation Between 1Y $\Delta$ in Credit-to-GDP at $\mathrm{t}+\mathrm{k}$ and the Current Account at $\mathrm{t}$..........42

A.2. Correlation Between $2 \mathrm{Y} \Delta$ in Credit-to-GDP at $\mathrm{t}+\mathrm{k}$ and the Current Account at $\mathrm{t}$..........43

A.3. Correlation Between $3 \mathrm{Y} \Delta$ in Credit-to-GDP at $\mathrm{t}+\mathrm{k}$ and the Current Account at $\mathrm{t}$..........44

Appendix Figures

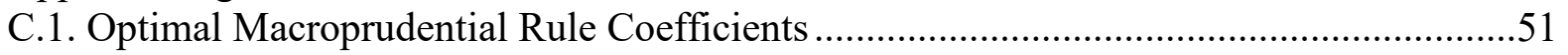

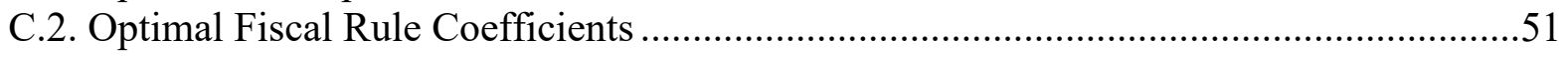

C.3. Macroprudential Rule Responding to House Price Fluctuations .....................................52 


\section{Introduction}

Global imbalances (i.e. the evolution of the world's current account surpluses and deficits) increased sharply in the run-up to the global financial crisis. Their evolution is monitored by the IMF and other policy institutions to understand risks to the global economy. ${ }^{1}$ In this paper, we examine the role that changes in credit and fiscal positions play in explaining current account fluctuations. The current account balance must equal the difference between an economy's aggregate savings and investment, which in turn can be decomposed into private and public savings and investment imbalances. It thus follows that the availability of financing both for the private and public sector is likely to be a main driver of current account balances. These effects have been emphasized in the vast literature analyzing global imbalances, together with other macroeconomic and structural fundamentals that may also affect the current account. ${ }^{2}$

Over the last decade, a large body of literature has studied how boom-and-bust cycles in credit have important macroeconomic effects, see for instance Mendoza and Terrones (2012), Dell'Ariccia et al. (2016), and Gourinchas et al. (2001). ${ }^{3}$ These papers document the relationship between credit booms and busts and the current account, which is negative: countries experiencing a credit boom also witness a deterioration of their current account balances, while countries in a credit bust tend to have improving current accounts. These contributions study how credit comoves with many macroeconomic indicators and do not specifically focus on the drivers of the relationship between credit and the current account. A few other papers, such as Adam et al. (2011) and Ferrero (2015), provide a more structural explanation by emphasizing the role that housing booms have played in driving current account balances, through the relaxation of collateral constraints that may also trigger a credit boom. The relationship between fiscal policy and the current account has also been widely covered in the "twin deficits" literature (see the surveys by Cavallo, 2005 and Bartolini and Lahiri, 2006, and the references therein).

\footnotetext{
${ }^{1}$ The IMF's External Sector Report analyzes global external developments and provides multilaterally consistent assessments of economies' external positions (see International Monetary Fund, 2019, 2020).

${ }^{2}$ These factors include demographics, differences in income per capita, institutional quality and others; see for instance Cubeddu et al. (2019); Gruber and Kamin (2007); Chinn and Prasad (2003); Coutinho et al. (2018); Chinn et al. (2014) and Turrini and Zeugner (2019).

${ }^{3}$ See also Mian and Sufi (2011, 2014); Mian, Rao and Sufi (2013); Jones, Midrigan and Philippon (2020).
} 
In this paper, we revisit the empirical relationship between credit, fiscal and the current account in a sample of 38 advanced and emerging economies. Regarding the relationship between credit and the current account, we confirm the results of the existing literature: when credit increases, the current account declines. We also confirm the results from the "twin deficits" literature: the fiscal balance positively comoves with the current account. However, we find that there is important heterogeneity across countries when studying these relationships. We use this evidence to motivate the use of a two-country international real business cycle model (in the spirit of Heathcote and Perri, 2002) with financial frictions (as in Jones, Midrigan and Philippon, 2020) to quantify the importance of credit shocks for the current account. ${ }^{4}$ The model is also used to study the role of fiscal policy in explaining current account fluctuations.

The use of a structural model helps in understanding what forces are at play in determining an economy's external balance, as well as the role of alternative policies in determining outcomes. For instance, a credit boom driven by a relaxation of lending standards will likely boost domestic consumption and investment, and lead to a current account deficit. But a credit increase driven by improved productivity may lead to a current account surplus if output expands more than domestic demand. Similarly, the reaction of fiscal policy to other shocks in the economy, and whether it is procyclical or countercyclical, can affect the relationship between the fiscal balance and the current account. For instance, a fiscal expansion that is trying to offset a domestic demand shortfall does not have to increase the current account deficit. But, a fiscal expansion that is implemented when an economy is already experiencing robust private demand growth certainly will.

We estimate the model using annual data for the U.S. and a "rest of the world" aggregate that includes main advanced economies, using a Generalized Method of Moments approach (as in Andreasen et al., 2018). Importantly, the model has a flexible specification that allows for the strength of the credit channel to be determined in the estimation. The estimated model is successful at matching the comovement between credit, fiscal policy and the current account, and can be used to understand the drivers of the U.S. current account balance. We find that

\footnotetext{
${ }^{4}$ Cesa-Bianchi et al. (2018) use a two-country macroeconomic model with financial frictions to understand the transmission of international credit shocks.
} 
about 30 percent of the U.S. current account balance fluctuations are due to domestic credit shocks, and about one-third are explained by foreign credit shocks, while the importance of fiscal shocks is somewhat smaller, at about 14 percent. We find that, absent U.S. credit and fiscal shocks, the U.S. current account deficit would have been much smaller and less volatile, especially during the 1995-2006 period when the deficit grew from less than 2 percent of GDP to almost 6 percent of GDP.

In the final section of the paper, we evaluate simple macroprudential policy rules and show that they could help reduce global imbalances. By taming the domestic financial cycle, macroprudential rules that react to domestic credit conditions or to domestic house prices would have lead to a smaller and less volatile U.S. current account deficit. We also show that a countercylical fiscal policy rule that aims at stabilizing domestic output growth would also help to reduce the level and volatility of the U.S. current account. Since the large U.S. current account deficit must be mirrored by current account surpluses elsewhere, we conclude that countercyclical fiscal and credit policies in the U.S. would have helped in reducing global imbalances over the last three decades. ${ }^{5}$ We emphasize that these policy rules target domestic indicators and not the current account per se, and are calibrated to maximize domestic welfare. Nonetheless, we find these policies have implications for the level and volatility of the current account.

The paper is organized as follows. Section 2 presents the empirical evidence and discusses the comovement between credit, the fiscal balance, and the current account. Section 3 presents the two-country model with financial frictions and fiscal policy. Section 4 details the estimation procedure and shows key implications of the estimated model. Section 5 presents counterfactual exercises and the effects of macroprudential and fiscal policy rules. Section 6 concludes.

\section{Empirical Evidence}

This section provides extensive evidence on the negative relationship between credit and the current account for a group of advanced and emerging market economies. Credit expansions

\footnotetext{
${ }^{5}$ This result would also hold if other economies also conducted countercyclical macruprudential and fiscal policies. However, we emphasize U.S. policies because the U.S. has a large impact in the global economy given its size.
} 
(contractions) are typically associated with increasing (decreasing) current account deficits, and this relationship is robust to alternatives ways of filtering the credit data to extract its cyclical component. This section also presents updated evidence on the positive relationship between fiscal and current account balances, a relationship that has been studied previously and labelled as "twin deficits" in the literature (see Cavallo, 2005, Bartolini and Lahiri, 2006, and the references therein).

\subsection{The Relationship between Credit and the Current Account}

We estimate a measure of cyclical fluctuations of the credit-to-GDP ratio (i.e. the credit gap) by applying the methodology developed by the Bank for International Settlements (BIS). We used the filtered credit-to-GDP series to study the relationship between the cyclical component of credit and the current account at the annual frequency. The BIS methodology, explained in Drehmann et al. (2011), consists in applying a one-sided Hodrick-Prescott filter to the private sector credit-to-GDP ratio with a large penalty parameter. ${ }^{6}$ Then, we study the comovement between the credit gap and the current account balance-to-GDP ratio. ${ }^{7}$

Table 1 presents the results for a sample of 38 systemic economies, including both advanced and emerging economies, for the 1986-2017 period. For a large majority of countries, the contemporaneous correlation between the credit gap and the current account is negative (in 31 out of 38 countries). On average, the contemporaneous correlation between the credit gap and the current account is -0.41 , with small differences between the group of advanced economies $(-0.38)$ and emerging and developing economies $(-0.45)$. The corresponding median values show an even stronger negative correlation between the credit gap and the current account ( -0.56 for advanced economies and -0.51 for emerging market and developing economies). While there is some cross-country heterogeneity, on average, the peak correlation occurs when

\footnotetext{
${ }^{6}$ Drehmann et al. (2011) suggest using a penalty value (a "lambda") of 400,000 using quarterly data. Since we use annual data, we use a penalty parameter of 25,000 in the one-sided Hodrick and Prescott filter.

${ }^{7}$ The literature on the effects of credit booms and busts proceeds as follows. First, a credit boom phase and a credit bust phase is identified in the data. Then, the behavior of main macroeconomic variables is studied around those credit booms and busts (see Mendoza and Terrones, 2012, and Gourinchas et al., 2001, for details). We take a complementary approach by studying the relationship between the cyclical component of credit and the current account at all times, without having to date when credit booms and busts occur. Our results are qualitatively similar to this literature.
} 
Table 1: Correlation Between the Credit Gap at $t+k$ and the Current Account at $t$

\begin{tabular}{|c|c|c|c|c|c|c|c|}
\hline Country $\backslash k$ & -3 & -2 & -1 & 0 & 1 & 2 & 3 \\
\hline Argentina & -0.50 & -0.67 & -0.64 & -0.40 & -0.32 & -0.41 & -0.28 \\
\hline Australia & -0.12 & -0.29 & -0.46 & -0.57 & -0.44 & -0.31 & -0.24 \\
\hline Austria & 0.03 & 0.05 & 0.07 & 0.08 & 0.08 & 0.00 & -0.08 \\
\hline Belgium & 0.17 & 0.24 & 0.23 & 0.13 & 0.34 & 0.30 & 0.27 \\
\hline Brazil & 0.24 & 0.26 & 0.15 & -0.16 & -0.47 & -0.49 & -0.30 \\
\hline Canada & -0.28 & -0.36 & -0.51 & -0.67 & -0.69 & -0.61 & -0.52 \\
\hline Chile & -0.42 & -0.34 & -0.35 & -0.37 & -0.29 & -0.16 & -0.13 \\
\hline China & 0.00 & -0.20 & -0.45 & -0.66 & -0.68 & -0.54 & -0.28 \\
\hline Colombia & -0.47 & -0.64 & -0.79 & -0.78 & -0.63 & -0.45 & -0.35 \\
\hline Czech Republic & 0.24 & 0.32 & 0.33 & 0.37 & 0.57 & 0.70 & 0.75 \\
\hline Denmark & -0.45 & -0.53 & -0.57 & -0.58 & -0.50 & -0.36 & -0.15 \\
\hline Finland & -0.01 & -0.26 & -0.48 & -0.63 & -0.71 & -0.74 & -0.71 \\
\hline France & -0.53 & -0.66 & -0.80 & -0.81 & -0.77 & -0.70 & -0.60 \\
\hline Germany & -0.54 & -0.55 & -0.56 & -0.55 & -0.59 & -0.56 & -0.49 \\
\hline Greece & -0.88 & -0.91 & -0.89 & -0.81 & -0.65 & -0.43 & -0.21 \\
\hline Hungary & -0.73 & -0.63 & -0.51 & -0.35 & -0.10 & 0.15 & 0.35 \\
\hline India & 0.59 & 0.41 & 0.20 & 0.06 & -0.06 & -0.26 & -0.42 \\
\hline Indonesia & -0.34 & -0.56 & -0.77 & -0.82 & -0.81 & -0.69 & -0.55 \\
\hline Ireland & 0.24 & -0.20 & -0.45 & -0.65 & -0.73 & -0.78 & -0.79 \\
\hline Italy & -0.43 & -0.67 & -0.83 & -0.85 & -0.75 & -0.55 & -0.27 \\
\hline Japan & 0.09 & 0.07 & -0.02 & -0.18 & -0.34 & -0.47 & -0.51 \\
\hline Malaysia & -0.49 & -0.67 & -0.76 & -0.73 & -0.62 & -0.56 & -0.57 \\
\hline Korea & -0.08 & -0.29 & -0.37 & -0.13 & 0.13 & 0.12 & 0.03 \\
\hline Mexico & -0.09 & -0.31 & -0.53 & -0.72 & -0.72 & -0.65 & -0.49 \\
\hline Netherlands & -0.04 & -0.20 & -0.23 & -0.12 & -0.08 & -0.15 & -0.27 \\
\hline Norway & 0.47 & 0.33 & 0.11 & -0.08 & -0.02 & 0.09 & 0.12 \\
\hline Peru & -0.51 & -0.58 & -0.65 & -0.60 & -0.44 & -0.26 & -0.08 \\
\hline Poland & -0.32 & -0.44 & -0.50 & -0.64 & -0.59 & -0.42 & -0.19 \\
\hline Portugal & -0.52 & -0.68 & -0.74 & -0.77 & -0.74 & -0.71 & -0.69 \\
\hline Russia & 0.52 & 0.33 & 0.15 & 0.05 & 0.06 & -0.08 & -0.32 \\
\hline South Africa & 0.46 & 0.34 & 0.17 & 0.07 & 0.13 & 0.27 & 0.33 \\
\hline Spain & -0.44 & -0.64 & -0.79 & -0.86 & -0.86 & -0.78 & -0.65 \\
\hline Sweden & 0.36 & 0.25 & 0.09 & -0.07 & -0.19 & -0.29 & -0.34 \\
\hline Switzerland & -0.02 & -0.15 & -0.25 & -0.18 & -0.12 & -0.23 & -0.29 \\
\hline Thailand & -0.59 & -0.67 & -0.61 & -0.43 & -0.23 & -0.08 & 0.02 \\
\hline Turkey & -0.74 & -0.76 & -0.79 & -0.81 & -0.68 & -0.59 & -0.55 \\
\hline United Kingdom & 0.32 & 0.25 & 0.24 & 0.25 & 0.26 & 0.26 & 0.25 \\
\hline United States & -0.42 & -0.60 & -0.69 & -0.64 & -0.54 & -0.42 & -0.30 \\
\hline Full sample, Mean & -0.16 & -0.28 & -0.38 & -0.41 & -0.36 & -0.31 & -0.25 \\
\hline Full sample, Median & -0.20 & -0.32 & -0.49 & -0.56 & -0.46 & -0.41 & -0.29 \\
\hline AEs, Mean & -0.13 & -0.25 & -0.34 & -0.38 & -0.33 & -0.30 & -0.26 \\
\hline AEs, Median & -0.06 & -0.27 & -0.46 & -0.56 & -0.47 & -0.39 & -0.28 \\
\hline EMDEs, Mean & -0.21 & -0.32 & -0.42 & -0.45 & -0.40 & -0.33 & -0.24 \\
\hline EMDEs, Median & -0.38 & -0.50 & -0.52 & -0.51 & -0.46 & -0.41 & -0.29 \\
\hline
\end{tabular}

Sources: IMF World Economic Outlook database, Bank for International Settlements, World Development Indicators and authors' calculations. 
Figure 1: Correlation between the Credit Gap and the Current Account
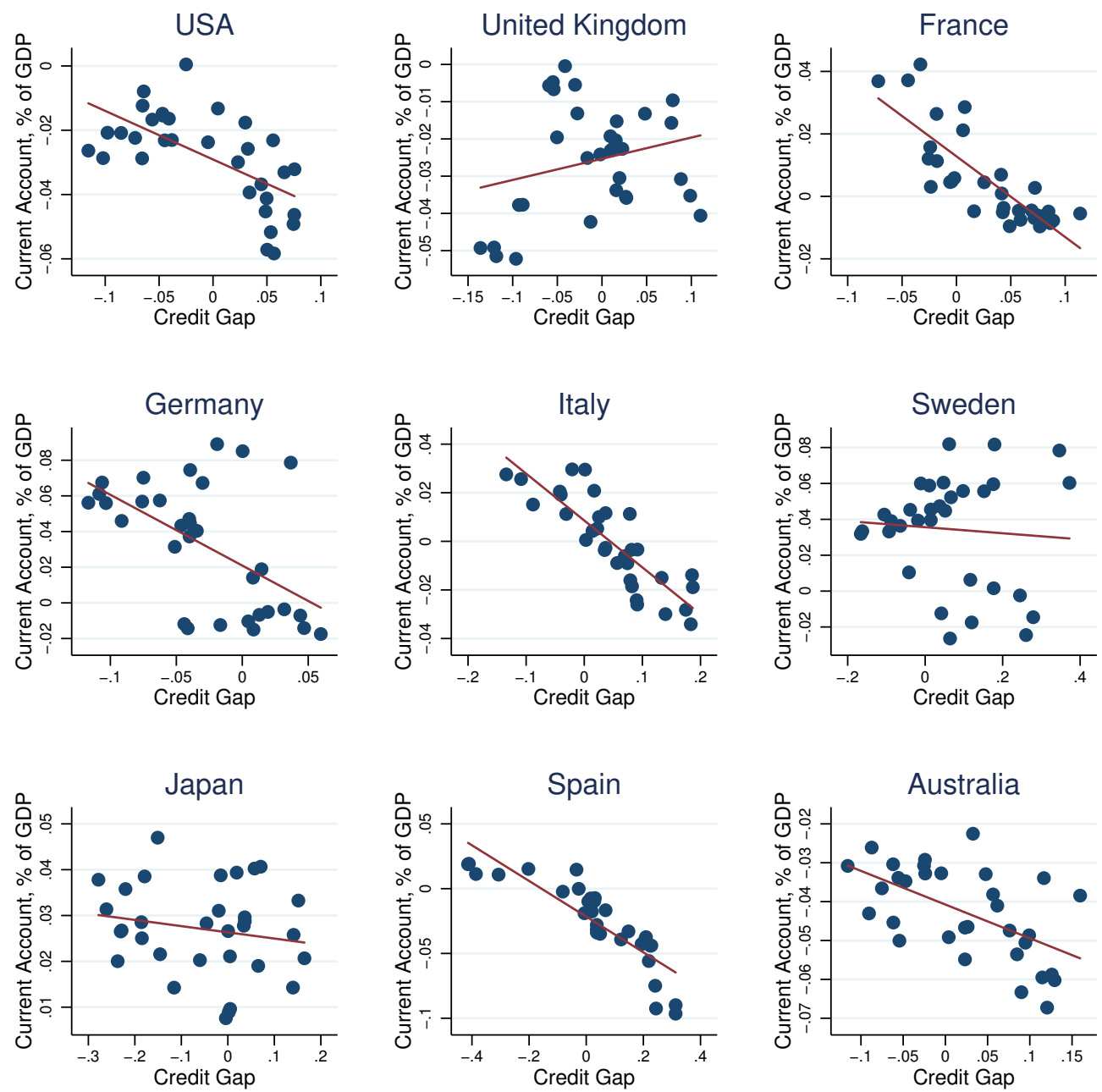

Sources: IMF World Economic Outlook database, Bank for International Settlements, World Development Indicators and authors' calculations.

$k=0$, which means that the strongest comovement occurs contemporaneously.

Figure 1 presents the scatterplot for a group of selected advanced economies, where each dot denotes one annual observation. The correlation is large and negative for countries that experienced a credit boom and bust together with large changes in their current accounts, such as Spain $(-0.86)$ and the United States $(-0.64)$. In other countries with milder credit fluctuations, such as France, Germany, and Italy, the correlation is also large and negative, ranging from -0.55 to -0.85 . In a few cases, the correlation is weaker, such as in Sweden $(-0.07)$ and Japan $(-0.18)$, or even mildly positive (United Kingdom, 0.25). Table 1 shows that this relationship also holds for important emerging economies such as China $(-0.66)$, 
Colombia (-0.78), Malaysia (-0.73), Mexico (-0.72), Thailand $(-0.43)$ and Turkey $(-0.81)$.

The relationship between the cyclical component of credit-to-GDP and the current account is robust to how the credit-to-GDP series is filtered. As an alternative to the BIS-style credit gap, we also study the correlation between the cumulative annual change in the credit to GDP ratio, using a window of 1 to 3 years, and the current account. By using a wider window, we check whether persistent changes in the credit-to-GDP ratio that occur over a few years have a stronger effect on the current account than simply one-year fluctuations. We report these statistics in Tables A.1 to A.3 in the Appendix. For all cases, the correlation is negative, and it becomes more so when the window considered is three years. For the entire sample, the average correlation between the annual change in the credit-to-GDP ratio and the current account-to-GDP ratio is -0.34 , while the correlation between the 3 -year cumulative change in the credit-to-GDP ratio and the current account-to-GDP ratio is -0.39 .

\subsection{The Relationship between the Fiscal Balance and the Current Account}

Next, we revisit the role of fiscal policy in affecting the current account. Table 2 presents, for the same country and time sample, the correlation between the fiscal balance and the current account at an annual frequency. For a majority of countries (31 out of 38 countries), this relationship is positive: fiscal deficits go hand-in-hand with current account deficits, a fact labelled "twin deficits" in the literature. ${ }^{8}$ This relationship is stronger in advanced economies, where the average correlation is 0.29 , than in emerging markets and developing economies, where the correlation is 0.08 , although median correlations are more similar (0.29 vs 0.25).

Figure 2 presents the scatterplot for the same group of economies as in Figure 1. In most cases, the correlation is positive and ranges from 0.84 in Sweden, 0.61 in Germany, about 0.40 in France and Italy, 0.33 in Japan and 0.29 in the United States. On the other hand, Spain (0.01) and Australia $(-0.33)$ are exceptions among the group of selected advanced economies. Finally, it is important to remark that this relationship is somewhat weaker in emerging and

\footnotetext{
${ }^{8}$ For empirical evidence on the link between the fiscal balance and the current account see Abbas et al. (2011), Gruber and Kamin (2007), and Cubeddu et al. (2019).
} 
Table 2: Correlation Between the Fiscal Balance at $t+k$ and the Current Account at $t$

\begin{tabular}{|c|c|c|c|c|c|c|c|}
\hline Country $\backslash k$ & -3 & -2 & -1 & 0 & 1 & 2 & 3 \\
\hline Argentina & 0.37 & 0.65 & 0.65 & 0.52 & 0.14 & 0.06 & 0.05 \\
\hline Australia & 0.21 & -0.13 & -0.28 & -0.33 & -0.47 & -0.44 & -0.38 \\
\hline Austria & 0.04 & -0.04 & 0.16 & 0.27 & 0.39 & 0.36 & 0.37 \\
\hline Belgium & 0.34 & 0.28 & 0.19 & 0.07 & -0.05 & -0.18 & -0.29 \\
\hline Brazil & 0.48 & 0.52 & 0.44 & 0.26 & 0.17 & 0.02 & -0.12 \\
\hline Canada & 0.57 & 0.65 & 0.71 & 0.70 & 0.63 & 0.54 & 0.45 \\
\hline Chile & 0.06 & 0.20 & 0.34 & 0.24 & 0.04 & -0.06 & -0.05 \\
\hline China & 0.35 & 0.30 & 0.33 & 0.45 & 0.42 & 0.29 & -0.02 \\
\hline Colombia & 0.33 & 0.40 & 0.43 & 0.28 & -0.03 & -0.37 & -0.49 \\
\hline Czech Republic & 0.31 & 0.55 & 0.62 & 0.43 & 0.68 & 0.53 & 0.04 \\
\hline Denmark & 0.26 & 0.15 & 0.12 & 0.16 & 0.13 & 0.13 & 0.26 \\
\hline Finland & 0.70 & 0.67 & 0.61 & 0.54 & 0.44 & 0.33 & 0.17 \\
\hline France & 0.35 & 0.49 & 0.44 & 0.40 & 0.37 & 0.29 & 0.17 \\
\hline Germany & 0.49 & 0.53 & 0.58 & 0.61 & 0.54 & 0.45 & 0.37 \\
\hline Greece & 0.16 & 0.34 & 0.46 & 0.47 & 0.37 & 0.23 & 0.01 \\
\hline Hungary & 0.28 & 0.36 & 0.54 & 0.69 & 0.71 & 0.57 & 0.30 \\
\hline India & -0.16 & -0.20 & -0.23 & -0.18 & -0.19 & -0.15 & -0.11 \\
\hline Indonesia & 0.17 & 0.27 & 0.22 & 0.19 & 0.09 & 0.11 & 0.15 \\
\hline Ireland & 0.78 & 0.58 & 0.50 & 0.28 & 0.08 & -0.05 & -0.15 \\
\hline Italy & 0.23 & 0.32 & 0.38 & 0.39 & 0.30 & 0.16 & -0.04 \\
\hline Japan & -0.32 & -0.14 & 0.20 & 0.33 & 0.26 & 0.06 & -0.20 \\
\hline Korea & -0.06 & 0.20 & 0.04 & 0.01 & -0.14 & -0.16 & -0.20 \\
\hline Malaysia & -0.61 & -0.78 & -0.82 & -0.59 & -0.50 & -0.37 & -0.27 \\
\hline Mexico & 0.03 & 0.11 & -0.15 & -0.29 & -0.36 & 0.10 & 0.32 \\
\hline Netherlands & 0.35 & 0.35 & 0.29 & 0.15 & 0.01 & -0.23 & -0.12 \\
\hline Norway & 0.31 & 0.27 & 0.32 & 0.35 & 0.37 & 0.37 & 0.46 \\
\hline Peru & 0.42 & 0.57 & 0.42 & 0.38 & 0.27 & 0.17 & 0.29 \\
\hline Poland & -0.23 & -0.19 & -0.16 & 0.27 & 0.19 & 0.26 & -0.11 \\
\hline Portugal & 0.22 & 0.27 & 0.18 & 0.13 & 0.00 & -0.27 & -0.39 \\
\hline Russia & 0.43 & 0.56 & 0.65 & 0.65 & 0.41 & 0.03 & -0.10 \\
\hline South Africa & -0.03 & -0.14 & -0.30 & -0.38 & -0.37 & -0.32 & -0.30 \\
\hline Spain & 0.48 & 0.41 & 0.28 & 0.01 & -0.28 & -0.46 & -0.61 \\
\hline Sweden & 0.90 & 0.93 & 0.90 & 0.84 & 0.76 & 0.67 & 0.59 \\
\hline Switzerland & 0.61 & 0.50 & 0.28 & 0.08 & -0.03 & -0.06 & -0.04 \\
\hline Thailand & -0.07 & -0.22 & -0.53 & -0.70 & -0.69 & -0.61 & -0.44 \\
\hline Turkey & -0.34 & -0.34 & -0.36 & -0.31 & -0.21 & -0.29 & -0.12 \\
\hline United Kingdom & 0.51 & 0.47 & 0.34 & 0.27 & 0.24 & 0.23 & 0.33 \\
\hline United States & 0.75 & 0.60 & 0.42 & 0.29 & 0.15 & 0.03 & -0.09 \\
\hline Full sample, Mean & 0.26 & 0.27 & 0.24 & 0.21 & 0.13 & 0.05 & -0.01 \\
\hline Full sample, Median & 0.31 & 0.33 & 0.32 & 0.27 & 0.15 & 0.06 & -0.04 \\
\hline AEs, Mean & 0.37 & 0.37 & 0.35 & 0.29 & 0.22 & 0.11 & 0.03 \\
\hline AEs, Median & 0.35 & 0.38 & 0.33 & 0.29 & 0.25 & 0.15 & -0.01 \\
\hline EMDEs, Mean & 0.09 & 0.13 & 0.09 & 0.09 & 0.01 & -0.03 & -0.06 \\
\hline EMDEs, Median & 0.12 & 0.23 & 0.27 & 0.25 & 0.06 & 0.02 & -0.11 \\
\hline
\end{tabular}

Sources: IMF World Economic Outlook database and authors' calculations. 
Figure 2: Correlation between the Fiscal Balance and the Current Account
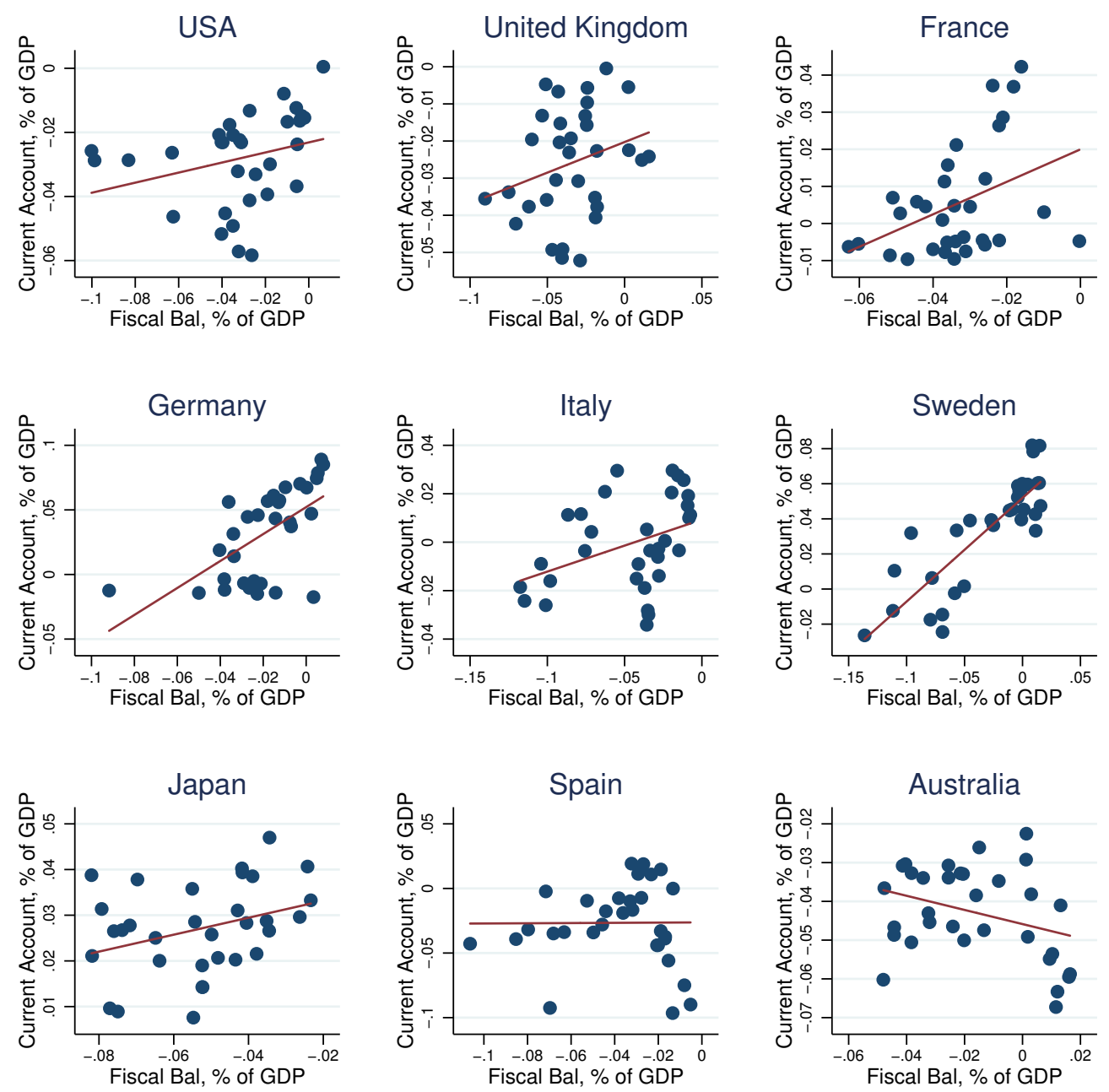

Sources: IMF World Economic Outlook database and authors' calculations.

developing economies, although it is positive in Brazil (0.26), China (0.45), Colombia (0.28) and Peru (0.38).

\section{Model}

The empirical analysis in the previous section provides suggestive evidence using bilateral correlations. To understand which factors are at play for the dynamics of the current account, we use an open economy DSGE model. Given the significant and important comovement of credit, the fiscal balance and the current account, our model incorporates credit explicitly through financial frictions and fiscal policy to study the relationship between these two variables and 
the current account. The model also allows us to understand the main sources of fluctuations, since different shocks help explain different patterns of comovement between the key variables of interest in the data.

We use an international real business cycle model with trade in intermediate goods and credit frictions. There are two countries in our model, labeled Home and Foreign. The trade and production structure is standard, as in Heathcote and Perri (2002). The final good produced in each country is used for consumption and investment in country-specific capital. Firms in each country produce intermediate goods using capital and labor, and sell those intermediate goods to final goods producers in both countries who combine their domestically-produced goods and imports into the final good. Households derive utility from consumption of the final good, from housing goods, and from leisure. Our model is annual, and thus we abstract from nominal frictions and countercyclical monetary policy rules that are not central to our analysis.

Credit frictions in our model are introduced in the following way, as in Jones, Midrigan and Philippon (2020). The representative household in our economy is comprised of a continuum of members whose consumption is subject to individual-specific preference shocks. We explicitly distinguish between liquid and illiquid assets on households' balance sheets and assume that households allocate their wealth between these two assets prior to the realization of the individual-specific preference shocks. The consumption of each individual member of a household is limited by a liquidity constraint. Households also face a borrowing constraint tied to the value of their housing that limits the extent to which they can tap the equity in their homes. We introduce shocks to this borrowing constraint that loosens or tightens it. We call these shocks credit shocks. ${ }^{9}$

In equilibrium, households will borrow up to the borrowing limit to alleviate the liquidity constraints. The extent to which the liquidity constraints are binding on the members of the household depends on the volatility of the idiosyncratic preference shocks. If the distribution

\footnotetext{
${ }^{9}$ As discussed in Jones, Midrigan and Philippon (2020) the form that these credit shocks take is not critical. They are introduced here as shocks to the demand for borrowing tied to the value of housing. An alternative approach would be to model credit intermediaries and allow for credit shocks to impact the cost at which intermediaries supply credit. The expansion and contraction of credit in the economy would thus reflect changes in the supply of credit. What is important is to match the evolution of the quantity of debt and have a mechanism which affects the portfolio choice households face when allocating resources between liquid and illiquid assets.
} 
of those shocks is large, liquidity is valuable and households find it optimal to cut consumption in response to a tightening of credit rather than dip into their liquid assets. In contrast, if the distribution of these shocks is small, liquidity is less valued and households find it optimal to use their savings to smooth consumption intertemporally following a shock. We will use the cross-country comovement in household debt and consumption to pin down the extent to which these liquidity constraints bind and thus govern the importance of credit shocks.

We use this framework instead of a more standard borrower-saver model as, for example, Iacoviello (2005) and Ferrero (2015). In a standard open-economy borrower-saver model, changes in credit lead one-for-one to changes in consumption. ${ }^{10}$ We do not want to impose a priori an important role for credit and our approach will allow us to estimate from the cross-country evidence the relationship between changes in credit and real variables. The model we use also ensures that households in a country are neither borrowers or savers ex-ante.

We will next detail the key equations of the model and leave the full exposition of the model to the Appendix. We will describe the equations as they apply to the Home country. The Foreign country's equations mirror those of the Home country. The variables and parameters of the Foreign country are denoted with asterixes.

\subsection{Production}

We start by describing first the production side of the economy. We will then describe the problem of the households and fiscal policy. Competitive intermediate goods-producing firms in the Home country produce output $\tilde{y}_{t}$ with labor $n_{t}$ and capital $k_{t-1}$ :

$$
\tilde{y}_{t}=\xi_{z, t} k_{t-1}^{\omega} n_{t}^{1-\omega}
$$

where $\omega$ is the Cobb-Douglas weight and $\xi_{z, t}$ is an autoregressive productivity process:

$$
\log \xi_{z, t}=\rho_{z} \log \xi_{z, t-1}+\sigma_{z} \varepsilon_{z, t}
$$

\footnotetext{
${ }^{10}$ Ferrero (2015) for example, finds in an experiment loosening the borrowing constraint, that there is an almost perfect $(-0.98)$ negative correlation between house prices and the current account.
} 
where $\rho_{z}$ governs the persistence of the productivity process, $\varepsilon_{z, t}$ is the home-specific productivity innovation scaled by $\sigma_{z}$. Firms in the Home country produce and sell their output for price $P_{t}^{H}$ to final goods producers who construct the composite final good which sells at price $P_{t}$. The rental rate on capital in the Home country is, in terms of final goods:

$$
r_{t}=\xi_{z, t} \frac{P_{t}^{H}}{P_{t}} \omega\left(\frac{n_{t}}{k_{t-1}}\right)^{1-\omega}
$$

while wages equal the marginal product of labor:

$$
w_{t}=\xi_{z, t} \frac{P_{t}^{H}}{P_{t}}(1-\omega)\left(\frac{k_{t-1}}{n_{t}}\right)^{\omega}
$$

Define the composite final good produced in the Home country as:

$$
y_{t}=\left[\kappa^{\frac{1}{\sigma}}\left(y_{t}^{H}\right)^{\frac{\sigma-1}{\sigma}}+(1-\kappa)^{\frac{1}{\sigma}}\left(y_{t}^{F}\right)^{\frac{\sigma-1}{\sigma}}\right]^{\frac{\sigma}{\sigma-1}}
$$

where $y_{t}$ is the final good, $y_{t}^{H}$ is the inputs of intermediate goods produced at Home, $y_{t}^{F}$ is the intermediate imports of the Foreign good by the Home country, $\kappa$ governs the share of domestic inputs in the final good output, and $\sigma$ is the elasticity of substitution between Home and Foreign inputs. Under this production structure, the price of the final good is:

$$
P_{t}=\left[\kappa\left(P_{t}^{H}\right)^{1-\sigma}+(1-\kappa)\left(P_{t}^{F}\right)^{1-\sigma}\right]^{\frac{1}{1-\sigma}}
$$

The resource constraint for the final good in the Home country is

$$
y_{t}=\int c_{i t} \mathrm{~d} i+k_{t}-(1-\delta) k_{t-1}+\frac{\phi_{k}}{2} k_{t-1}\left(\frac{k_{t}}{k_{t-1}}-1\right)^{2}+g_{t}
$$

where $c_{i t}$ is the consumption of an individual member $i$ of the household, $\delta$ is the depreciation rate of capital, $\phi_{k}$ governs the degree of capital adjustment costs, and $g_{t}$ denotes government spending, described in more detail below. The resource constraint for the intermediate good at Home is the sum of Home inputs into final goods production at Home, and the exports of Home 
goods to the Foreign intermediate producers:

$$
\tilde{y}_{t}=y_{t}^{H}+y_{t}^{H *}
$$

\subsection{Households}

Households are comprised of a continuum of members, indexed by $i$. The problem of the Home consumer is to:

$$
\max \sum_{t=0}^{\infty} \beta^{t}\left(\int v_{i t} \log c_{i t} \mathrm{~d} i+\eta^{h} \log h_{t}-\frac{1}{1+\nu} n_{t}^{1+\nu}\right)
$$

where $h_{t}$ is housing, $\beta$ is the discount factor, $\eta^{h}$ is a preference shifter for housing, and $\nu$ is the Frisch elasticity of substitution. The term $v_{i t}>1$ is the idiosyncratic taste shock specific to individual $i$ and which is drawn from a Pareto distribution

$$
\operatorname{Pr}\left(v_{i t} \leq v\right)=1-v^{-\alpha}
$$

The lower is $\alpha$, the more dispersion there is in the idiosyncratic taste shocks, and thus the more uncertainty there is about consumption across members of a household. The parameter $\alpha$ is key for determining the strength of fluctuations in credit and how they relate to real variables like consumption and investment, as we discuss below in Section 3.4.

The budget constraint of the Home country household is:

$$
P_{t} x_{t}+e_{t}\left(h_{t+1}-h_{t}\right)+P_{t} i_{t}=w_{t} n_{t}+r_{t} k_{t-1}+q_{t} b_{t+1}-b_{t}+a_{t}-P_{t} t_{t}+b_{t}^{g}-\frac{1}{R_{t}} b_{t+1}^{g},
$$

where $x_{t}$ is the amount of funds that the household transfers to each of its members for consumption prior to the realization of the idiosyncratic preference shocks, $e_{t}$ is the price of housing, $q_{t}$ is the price of new borrowing $b_{t+1}, a_{t}$ is the amount that is saved, $t_{t}$ is lump-sum taxes levied by the home government, $b_{t}^{g}$ is domestic government debt, $R_{t}$ is the gross interest rate on 
government debt, and $i_{t}$ is investment given by:

$$
i_{t}=k_{t}-(1-\delta) k_{t-1}+\frac{\phi_{k}}{2} k_{t-1}\left(\frac{k_{t}}{k_{t-1}}-1\right)^{2}
$$

Households at home can borrow domestically or from abroad, and $q_{t}$ is the price of the bond in terms of domestic consumption goods. The household chooses this amount prior to the realization of the preference shocks $v_{i t}$. The quantity of savings is the amount of unused funds in the goods market:

$$
q_{t} a_{t+1}=P_{t}\left(x_{t}-\int c_{i t} \mathrm{~d} i\right)
$$

The Home consumer faces the liquidity constraint on purchases of consumption:

$$
P_{t} x_{t} \geq P_{t} c_{i t}
$$

Consumers also face a borrowing constraint restricting the value of new borrowing to be below the value of housing

$$
q_{t} b_{t+1} \leq m_{t} e_{t} h_{t+1}
$$

where $m_{t}$ is an autoregressive process subject to i.i.d. shocks which move the amount that households can borrow against the value of their housing:

$$
\log m_{t}=\left(1-\rho_{m}\right) \log \bar{m}+\rho_{m} \log m_{t-1}+\sigma_{m} \varepsilon_{m, t}
$$

where $\rho_{m}$ governs the persistence of $\log m_{t}, \bar{m}$ is the steady-state loan-to-value ratio in the economy, and $\varepsilon_{m, t}$ are i.i.d. shocks scaled by $\sigma_{m}$. We refer to shocks to $m_{t}$ as credit shocks.

Asset markets clear internationally, so that

$$
a_{t}+a_{t}^{*}=b_{t}+b_{t}^{*}
$$




\subsection{Fiscal Policy}

Next, we implement a simple fiscal policy regime to both countries. In terms of the home country's variables, we add exogenous government spending $g_{t}$, financed by a lump sum tax $t_{t}$ and government debt $b_{t}^{g}$ that is purchased at price $1 / R_{t}$. We assume that lump-sum taxes are determined by a debt-stabilizing rule:

$$
\frac{t_{t}}{y_{t}}=\frac{t}{y}+\phi_{b}\left(\frac{b_{t+1}^{g}}{P_{t} y_{t}}-\frac{b^{g}}{P y}\right),
$$

and that the government spending rule is:

$$
g_{t}=\frac{g}{y} y_{t}+\xi_{g, t}
$$

where $\xi_{g, t}$ is an autoregressive process subject to i.i.d. shocks:

$$
\log \xi_{g, t}=\rho_{g} \log \xi_{g, t-1}+\sigma_{g} \varepsilon_{g, t}
$$

where $\rho_{g}$ governs the persistence of $\log \xi_{g, t}$, and $\varepsilon_{g, t}$ are i.i.d. shocks scaled by $\sigma_{g}$. The government budget constraint is therefore

$$
\frac{1}{R_{t}} b_{t+1}^{g}-b_{t}^{g}=P_{t} g_{t}-P_{t} t_{t}
$$

By assumption, we impose that governments can only borrow domestically.

\subsection{Decision Rules}

Each period, the consumers in the Home country choose a consumption profile that is a function of the idiosyncratic preference shock $c_{t}(v)$, how much funds to allocate to the goods market $x_{t}$, housing services $h_{t+1}$, private debt $b_{t+1}$, and government debt $b_{t+1}^{g}$. Consumers in the Foreign country make similar choices. As in the exposition of the model, we describe the decision rules of consumers in the Home country for brevity and leave the equations governing those of the 
Foreign country to the Appendix.

The first order condition of the choice of funds to allocate to the goods market $x_{t}$ is

$$
P_{t} \mu_{t}=\frac{\beta}{q_{t}} P_{t} \mathbb{E}_{t} \mu_{t+1}+P_{t} \int_{0}^{1} \xi_{t}(v) \mathrm{d} F(v)
$$

where $\mu_{t}$ is the shadow value of wealth, or the multiplier on the budget constraint, and $\xi_{t}(v)$ is the Lagrange multiplier on the liquidity constraint with a realized idiosyncratic preference shock of $v$. The expression says that a transfer $x_{t}$ is valued at $P_{t} \mu_{t}$ today and any unused amount is valued at $\frac{\beta}{q_{t}} \mathbb{E}_{t} P_{t+1} \mu_{t+1}$ tomorrow. The transfer $x_{t}$ also provides liquidity services for all members of the household summarized in the last term.

The optimal choice of debt in the Home country $b_{t+1}$ is

$$
q_{t} \mu_{t}=\beta \mathbb{E}_{t} \mu_{t+1}+q_{t} \lambda_{t}
$$

where $\lambda_{t}$ is the Lagrange multiplier on the borrowing constraint. Debt is valued $q_{t} \mu_{t}$ and tomorrow is valued at $\mu_{t+1}$ units of the Home consumption good. Taking on debt also tightens the borrowing constraint $q_{t} \lambda_{t}$. The choice of government debt simply gives an Euler equation:

$$
\frac{1}{R_{t}} \mu_{t}=\beta \mathbb{E}_{t} \mu_{t+1}
$$

Due to the presence of liquidity and borrowing constraints, there is a wedge between the interest rate paid on government debt, $R_{t}$, and the implicit yield paid on private borrowing, $1 / q_{t}$. This wedge depends on the final terms in equations (22) and (23), and reflects how binding the liquidity and borrowing constraints are.

The choice of housing $h_{t+1}$ in the Home country is

$$
\lambda_{t} m_{t} e_{t}+\beta \eta^{h} \mathbb{E}_{t} \frac{1}{h_{t+1}}=\mu_{t} e_{t}-\beta \mathbb{E}_{t} e_{t+1} \mu_{t+1}
$$

An additional unit of housing relaxes the borrowing constraint $\left(\lambda_{t} m_{t} e_{t}\right)$ and provides utility services $\left(\beta \eta^{h} \mathbb{E}_{t} \frac{1}{h_{t+1}}\right)$, but entails a user cost $\left(\mu_{t} e_{t}\right)$ and can be sold tomorrow $\left(-\beta \mathbb{E}_{t} e_{t+1} \mu_{t+1}\right)$. 
The consumption profile $c_{t}(v)$ is

$$
c_{t}(v)=\min \left[\frac{v}{\frac{\beta}{q_{t}} P_{t} \mathbb{E}_{t} \mu_{t+1}}, x_{t}\right],
$$

which says that consumption is either optimally set or limited by the transfer $x_{t}$. Denote by $\underline{c}_{t}$ the consumption of the individual who has the lowest realization of the shock $v=1$, so that

$$
\underline{c}_{t}=\frac{1}{\frac{\beta}{q_{t}} P_{t} \mathbb{E}_{t} \mu_{t+1}} .
$$

We show in the Appendix that we can write the average level of consumption relative to the minimum level as

$$
\frac{c_{t}}{\underline{c}_{t}}=\frac{\alpha}{\alpha-1}\left[1-\frac{1}{\alpha}\left(\frac{\underline{c}_{t}}{x_{t}}\right)^{\alpha-1}\right] .
$$

In this expression, note that the final term is proportional to the fraction of consumers who are constrained, which from our assumption that the taste shocks follow a Pareto distribution is $\left(x_{t} / \underline{c}_{t}\right)^{-\alpha}$. Thus, the wider is the dispersion of individual taste shocks (the lower is $\alpha$ ), the larger the fraction of members who are constrained in their desired consumption by the availability of liquidity $x_{t}$, and the smaller is the gap between the average level of consumption and the minimum level of consumption.

The parameter $\alpha$ is key to governing the strength of the preference for liquidity services in our economy and the impact of shocks to credit availability $m_{t}$. When the dispersion of individual taste shocks is high ( $\alpha$ is low), the household has a strong desire to hold liquid assets so as to smooth consumption across its members within a period. In response to a credit tightening, the household maintains its liquid asset position by cutting consumption. In contrast, when the dispersion of individual taste shocks is low ( $\alpha$ is high), liquidity is less valuable, and the household taps its liquid asset holdings in response to a credit shock so as to smooth consumption across time.

Finally, the optimal choice of capital $k_{t}$ is

$$
P_{t} \mu_{t}+\phi_{k} P_{t} \mu_{t}\left(\frac{k_{t}}{k_{t-1}}-1\right)=\beta \mathbb{E}_{t} \mu_{t+1}\left[P_{t+1}(1-\delta)+r_{k, t+1}\right]+\beta \frac{\phi_{k}}{2} \mathbb{E}_{t} P_{t+1} \mu_{t+1}\left(\frac{k_{t}^{2}}{k_{t-1}^{2}}-1\right)
$$


and the optimal choice of labor supply is:

$$
n_{t}^{\nu}=\mu_{t} w_{t}
$$

The problem and decision rules in the foreign country are analogous, and detailed in the Appendix.

\section{Estimation}

After having presented the two-country model with financial frictions and fiscal policy, this section describes how the model is estimated. The first subsection explains how the dataset is constructed. The second subsection explains how the model is estimated using the Generalized Method of Moments (GMM) procedure and describes the main model parameters, while the last subsection presents some key model implications.

\subsection{Data}

We estimate the two-country model by assuming that the United States is the home county, and an aggregate of other advanced economies is the rest of the world or foreign country. The focus of the empirical analysis is to study how credit and fiscal policy comove with the current account in the United States. The "rest of the world" (ROW) aggregate includes: Australia, Canada, France, Germany, Italy,, Japan, Spain Sweden, and the United Kingdom. The sample period is 1980-2017 at annual frequency. The set of observable variables is as follows: for the U.S., we include the current account to GDP ratio, the fiscal balance to GDP ratio, the annual change in the private credit to GDP ratio and real GDP growth. For the rest of the world, we use the fiscal balance to GDP ratio, the annual change in the private credit to GDP ratio and real GDP growth. ${ }^{11}$ Using real growth data allows to identify the effects of productivity shocks

\footnotetext{
${ }^{11}$ We use the annual change in the credit-to-GDP ratio as this allows us to compute its theoretical correlation with the current account in the model, which is then helpful when applying the GMM methodology that compares selected moments in the model and in the data. As discussed in Section 2 and in the Appendix, the correlation between different transformations of the credit-to-GDP ratio and the current account is robust for the U.S.
} 
in the model.

The ROW aggregation is done as follows: the fiscal and credit to GDP ratios are computed using a weighted average of each variable for each country, using their nominal GDP in USD for each year as a weight. Real GDP growth is aggregated similarly, but using real GDP in USD for each year as a weight. We do not include the ROW current account as an observable variable since, in the model, it should be the counterpart of the U.S. current account balance but in the data it is not. This is because our measure of the ROW does not include all other countries that trade with the U.S.

\subsection{GMM Estimation and Parameter Estimates}

Following the methods in Andreasen, Fernandez-Villaverde and Rubio-Ramirez (2018), we estimate the model by taking a first-order approximation to the equilibrium conditions and applying a GMM methodology to match key moments in the data. The advantage of this methodology, compared to likelihood-based methods, is that it allows us to focus on the key features of data that are of particular interest. In our case, we are interested in matching the comovement between the current account, the fiscal balance, and credit. Let $\mathbf{z}_{t}$ denote the vector of seven macroeconomic time series we described above at an annual frequency. We estimate the model by matching the standard deviation of the variables, the contemporaneous second moments and the persistence in the data. Denote

$$
M_{t} \equiv\left[\begin{array}{c}
\operatorname{vech}\left(\mathbf{z}_{t} \mathbf{z}_{t}^{\prime}\right) \\
\operatorname{diag}\left(\mathbf{z}_{t} \mathbf{z}_{t}^{\prime}\right) \\
\operatorname{diag}\left(\mathbf{z}_{t} \mathbf{z}_{t-1}^{\prime}\right)
\end{array}\right]
$$

where the $\operatorname{vech}(\bullet)$ operator selects the lower triangular elements of a matrix and orders them in a vector, and the $\operatorname{diag}(\bullet)$ operator selects the diagonal elements of a matrix. The size of the $\mathbf{M}_{t}$ vector is $35 \times 1$.

Letting $\Theta$ denote the vector of structural parameters that we wish to estimate, the GMM 
estimator is given by:

$$
\hat{\Theta}_{G M M}=\arg \min \left(\frac{1}{T} \sum_{t=1}^{T} \mathbf{M}_{t}-\mathbb{E}[\mathbf{M}(\Theta)]\right)^{\prime} \mathbf{W}\left(\frac{1}{T} \sum_{t=1}^{T} \mathbf{M}_{t}-\mathbb{E}[\mathbf{M}(\Theta)]\right)
$$

where $\mathbb{E}\left([\mathbf{M}(\Theta)]\right.$ denotes the model-implied moments that are counterparts to $\mathbf{M}_{t}$ when taking a first-order approximation to the model conditions and evaluate them at $\Theta$. $\mathbf{W}$ is a weighting matrix, which is positive definite. We use a conventional two-step approach. First, we use as a weighthing matrix for $\mathbf{W}$ the inverse of the long-run variance of the sample moments when centered at their sample mean, $\left(\frac{1}{T} \sum_{t=1}^{T} \mathbf{M}_{t}-\overline{\mathbf{M}}\right)^{\prime}$, to obtain an initial estimate of the parameters denoted by $\hat{\Theta}_{0}$. Then, we use the inverse of the variance-covariance matrix of $\left(\frac{1}{T} \sum_{t=1}^{T} \mathbf{M}_{t}-\mathbb{E}\left[\mathbf{M}\left(\hat{\Theta}_{0}\right)\right]\right)$ as the weighting matrix, which is obtained with a Newey-West estimator with 3 lags (since we are using annual data) to obtain a final estimate of the parameters denoted by $\hat{\Theta}_{1} \cdot{ }^{12}$

Some parameters of the model are calibrated (using external information) while others are estimated. Table 3 presents the calibrated parameters of the model. The share of imports to GDP is set to 0.2 (which corresponds to a $\kappa$ of 0.8 ), which is close to the average value for the U.S. economy. The steady-state value of the credit shock denotes the average LTV of the U.S. economy using flow-of-funds data. The capital share of output and the depreciation rate of capital are set to standard values in the RBC literature (1/3 and 10\% annual, respectively). We also assume standard values for the real interest rate of 2 percent annual, and the Frisch elasticity of labor supply which is assumed to be 2. The aggregate housing to income ratio is set to 2.5, using the same value as Jones, Midrigan and Philippon (2020). The supply of the housing stock is normalized to one. Using these values together with the estimate for $\alpha$ pins down the discount factor $\beta$ and the weight of housing in the utility function $\eta^{H}$. The steadystate government spending to GDP ratio is assumed to be 20 percent of GDP, while the target debt-to-GDP ratio in the fiscal rule is assumed to be 60 percent. Given these parameters, the

\footnotetext{
${ }^{12}$ We use seven macroeconomic variables for estimation, while the model has six shocks. This is not an issue when estimating the model using GMM. However, to conduct counterfactual policy analysis exercises in Section 5, we need to extract the structural shocks of the model using a Kalman smoother. To avoid singularity issues, an observation error shock is included in the ROW output growth equation.
} 
ratio of government revenues to GDP is determined endogenously. The current account and the net international investment position of each country are assumed to be balanced in the steady state.

Table 3: Calibrated Parameters

\begin{tabular}{llc}
\hline$\kappa, \kappa^{*}$ & Share of domestic goods in domestic production & 0.8 \\
$\bar{h}$ & Housing stock & 1 \\
$r=1 / q-1$ & Real interest rate & 0.02 \\
$\bar{m}$ & Steady-state credit shock (Average LTV) & 0.29 \\
$\nu$ & Inverse Frisch elasticity labor supply & 2 \\
$\omega$ & Capital share of output & $1 / 3$ \\
$\delta$ & Depreciation rate & 0.1 \\
$g / Y, g^{*} / Y^{*}$ & Government spending to GDP ratio, U.S. and ROW & 0.2 \\
$b^{g} / Y, b^{g *} / Y^{*}$ & Debt to GDP ratio, U.S. and ROW & 0.6 \\
\hline
\end{tabular}

Table 4 presents the estimated parameters using GMM, together with their estimated standard deviation. We present the asymptotic standard errors which are computed using the asymptotic expression for the variance-covariance matrix of the parameters under GMM estimation and an optimal weighting matrix. The estimated value for the dispersion of taste shocks $\alpha$ is 2.38, smaller than the estimate in Jones, Midrigan and Philippon (2020), and a value that implies a discount factor of 0.945 and a spread between the interest rate and the rate of time preference of about 3.6 percent. At the country-level, we thus find a relatively strong preference for liquidity, which works to increase the endogenous correlation between credit and real variables. The elasticity of substitution between home and foreign goods $\sigma$ is estimated at 2.5, which is on the high side compared to standard calibrations of international business cycle models (such as Heathcote and Perri, 2016) but closer to estimates using disaggregated data (see Imbs and Mejean, 2015, for a discussion). The parameter estimates suggest a stronger reaction of the U.S. tax revenues to deviations of government debt from steady-state values than its ROW counterpart. Finally, the parameter that governs investment adjustment costs is estimated at 6.57. The estimates of the shock processes are not that informative on their own, so in the next subsection we discuss the model fit from these parameter estimates. 
Table 4: Estimated Parameters

\begin{tabular}{clcc}
\hline & Parameter & Point Estimate & Standard Dev \\
\hline$\alpha$ & Dispersion of Taste Shocks & 2.38 & 0.03 \\
$\sigma$ & Elasticity of Substitution H/F Goods & 2.50 & 0.64 \\
$\phi_{b}$ & U.S. Tax Response to Debt & 0.16 & 0.06 \\
$\phi_{b}^{*}$ & ROW Tax Response to Debt & 0.06 & 0.01 \\
$\phi_{k}$ & Investment Adjustment Costs & 6.57 & 1.88 \\
$\rho_{z}$ & U.S. TFP AR(1) Parameter & 0.98 & 0.01 \\
$\rho_{z}^{*}$ & ROW TFP AR(1) Parameter & 0.46 & 0.26 \\
$\rho_{m}$ & U.S. Credit Shock AR(1) Parameter & 0.997 & 0.002 \\
$\rho_{m}^{*}$ & ROW Credit Shock AR(1) Parameter & 0.80 & 0.14 \\
$\rho_{g}$ & U.S. Fiscal Shock AR(1) Parameter & 0.42 & 0.08 \\
$\rho_{g}^{*}$ & ROW Fiscal Shock AR(1) Parameter & 0.60 & 0.17 \\
$\sigma_{z}$ & U.S. TFP Innovation Std. Dev. & 1.33 & 0.07 \\
$\sigma_{z}^{*}$ & ROW TFP Innovation Std. Dev. & 0.83 & 0.30 \\
$\sigma_{m}$ & U.S. Credit Shock Innovation Std. Dev. & 4.26 & 0.33 \\
$\sigma_{m}^{*}$ & ROW Credit Shock Innovation Std. Dev. & 8.55 & 0.45 \\
$\sigma_{g}$ & U.S. Fiscal Shock Innovation Std. Dev. & 4.35 & 0.26 \\
$\sigma_{g}^{*}$ & ROW Fiscal Shock Innovation Std. Dev. & 2.41 & 0.19 \\
$\sigma_{\Delta y}^{*}$ & Measurement Error, ROW Output Growth & 1.00 & 0.34 \\
\hline Note: all the estimates for standard deviation of the shocks are expressed in percentage points.
\end{tabular}

\subsection{Model Implications: Impulse-Responses and Model Fit}

\subsubsection{Model Fit}

Table 5 and 6 shows how well the model fits the selected second moments in the data. The model does a good job in fitting most standard deviations in the data, in particular those that relate to the U.S. economy. The model underestimates the volatility of the change in the credit-to-GDP ratio in the ROW, but properly matches the volatility of the ROW real GDP growth. The model is also close to matching the persistence of the U.S. current account, and the ROW fiscal balances. On the other hand, it does a poor job in matching the persistence of the credit-to-GDP change and real GDP growth in both the U.S. and the ROW. ${ }^{13}$ The estimated model also matches the main features of the U.S. current account. In particular, it matches the negative correlation between credit and the current account, and the positive correlation

\footnotetext{
${ }^{13}$ The credit shocks in the model affect the persistence of the level of the credit-to-GDP ratio. One would need credit shocks with persistence in their growth rate to be able to match the persistence in the change of the credit-to-GDP ratio. However, this is not a trivial task since this would impose non-stationarity in the loan-to-value ratio, complicating the existence of a well-defined steady-state.
} 
Table 5: Model Fit

\begin{tabular}{|c|c|c|c|c|}
\hline \multirow[b]{2}{*}{ Variable } & \multicolumn{2}{|c|}{ Data } & \multicolumn{2}{|c|}{ Model } \\
\hline & Std. Dev. & Autocorr & Std. Dev. & Autocorr \\
\hline Current Account/GDP, U.S. & 1.51 & 0.86 & 1.51 & 0.63 \\
\hline Credit/GDP, Change, U.S. & 3.04 & 0.62 & 3.59 & -0.03 \\
\hline Fiscal Balance/GDP, U.S. & 3.01 & 0.81 & 2.43 & 0.38 \\
\hline Real GDP Growth, U.S. & 1.80 & 0.34 & 1.50 & 0.03 \\
\hline Credit/GDP, Change, ROW & 10.13 & 0.27 & 7.25 & -0.12 \\
\hline Fiscal Balance/GDP, ROW & 1.19 & 0.75 & 2.14 & 0.77 \\
\hline Real GDP Growth, ROW & 1.51 & 0.36 & 1.52 & -0.13 \\
\hline
\end{tabular}

Table 6: Model Fit, Correlations

\begin{tabular}{|c|c|c|c|c|c|}
\hline Correlation & Data & Model & Correlation & Data & Model \\
\hline (CA, CRE) & -0.44 & -0.29 & $\left(\mathrm{CRE}^{*}, \mathrm{GDP}\right)$ & -0.15 & 0.05 \\
\hline$\left(\mathrm{CA}, \mathrm{CRE}^{*}\right)$ & -0.19 & 0.44 & $\left(\mathrm{CRE}^{*}, \mathrm{GDP}^{*}\right)$ & -0.02 & -0.12 \\
\hline (CA, GDP) & -0.09 & -0.12 & $\left(\mathrm{CRE}^{*}, \mathrm{FB}\right)$ & -0.15 & 0.04 \\
\hline$\left(\mathrm{CA}, \mathrm{GDP}^{*}\right)$ & -0.04 & 0.03 & $\left(\mathrm{CRE}^{*}, \mathrm{FB}^{*}\right)$ & -0.17 & 0.04 \\
\hline$(\mathrm{CA}, \mathrm{FB})$ & 0.46 & 0.36 & $\left(\mathrm{GDP}, \mathrm{GDP}^{*}\right)$ & 0.65 & 0.02 \\
\hline$\left(\mathrm{CA}, \mathrm{FB}^{*}\right)$ & -0.26 & -0.15 & $(\mathrm{GDP}, \mathrm{FB})$ & 0.19 & -0.17 \\
\hline (CRE, CRE*) & 0.22 & -0.16 & $\left(\mathrm{GDP}, \mathrm{FB}^{*}\right)$ & 0.28 & 0.01 \\
\hline (CRE, GDP) & 0.19 & -0.18 & $(\mathrm{GDP}, * \mathrm{FB})$ & 0.28 & 0.01 \\
\hline$\left(\mathrm{CRE}, \mathrm{GDP}^{*}\right)$ & 0.20 & 0.02 & $\left(\mathrm{GDP}^{*}, \mathrm{FB}^{*}\right)$ & 0.21 & -0.04 \\
\hline$(\mathrm{CRE}, \mathrm{FB})$ & 0.31 & 0.20 & $\left(\mathrm{FB}, \mathrm{FB}^{*}\right)$ & 0.33 & -0.02 \\
\hline$\left(\mathrm{CRE}, \mathrm{FB}^{*}\right)$ & 0.62 & 0.01 & & & \\
\hline
\end{tabular}

Notes: CA is the U.S. current account balance to GDP ratio. CRE is the annual change in the U.S. credit-to-GDP ratio. FB is the U.S. fiscal balance to GDP ratio. GDP is the U.S. annual real GDP growth. Variables with an asterisk denote their rest of the world (ROW) counterparts.

between the fiscal balance and the current account for the United States, which are the key facts that we are interested in.

The estimated model also allows for a decomposition of the main sources of fluctuations. In Table 7 we present a variance decomposition exercise for the observable variables in the U.S. The model assigns multiple sources to the U.S. current account fluctuations, but the main ones are credit shocks originating in the U.S. and in the ROW, each explaining about 30 percent of the volatility of the current account. Domestic productivity shocks explain 18.6 percent while fiscal shocks explain 13.9 percent of the U.S. fiscal account, while the remaining ROW shocks have a very minor contribution. Interestingly, most of the fluctuations of the other three U.S. observable variables are mostly driven by just one shock. Specifically, fluctuations in the change 
Table 7: Variance Decomposition

\begin{tabular}{|c|c|c|c|c|c|c|}
\hline \multirow[b]{2}{*}{ Variables } & \multicolumn{2}{|c|}{ Productivity } & \multicolumn{2}{|c|}{ Credit } & \multicolumn{2}{|c|}{ Gov Spending } \\
\hline & U.S. & ROW & U.S. & ROW & U.S. & ROW \\
\hline Current Account to GDP & 18.6 & 0.4 & 28.9 & 33.2 & 13.9 & 4.9 \\
\hline U.S. Credit to GDP & 0.5 & 0.0 & 90.2 & 0.4 & 8.8 & 0.1 \\
\hline U.S. GDP Growth & 89.6 & 0.0 & 0.3 & 0.5 & 9.5 & 0.1 \\
\hline U.S. Fiscal Balance to GDP & 1.0 & 0.0 & 0.0 & 0.0 & 98.9 & 0.0 \\
\hline
\end{tabular}

in the credit-to-GDP ratio are largely driven by U.S. credit shocks, while fluctuations in GDP growth are driven by productivity shocks, and fluctuations in the fiscal balance are driven by government spending shocks.

\subsubsection{Impulse Responses}

After a U.S. credit market shock that increases households' ability to borrow, the private credit to output ratio increases to about 3 percent of GDP, with a highly persistent impact (Figure 3 ). The increased ability to borrow increases domestic consumption and investment, while output (understood as intermediate goods production) displays a hump-shaped response due to the initial decline of hours worked. As the level of employment increases and capital accumulates due to increased investment, output recovers. House prices increase under the credit shock, further relaxing borrowing constraints. Since the impact on domestic supply is smaller than on domestic demand, the current account moves into deficit, and converges back to zero monotonically. The fiscal balance moves to a slight deficit which is negligible in quantitative terms $(-0.03$ percent of GDP), due to the estimated fiscal rule.

After a U.S. increase in government spending, the model is able to replicate the "twin deficits" fact (Figure 4): both the fiscal and the current account balance turn into deficit as percent of GDP. The fiscal impulse is expansionary, leading to a short-lived increase in output, while the private credit-to-GDP ratio contracts, due to some crowding out from government borrowing that cannot be fully offset through international borrowing. The impact multiplier of the fiscal balance on the current account is about 0.25 , which is close to the coefficient estimated in single-equation models (see Abbas et al., 2011, which includes a survey of the 
Figure 3: Impulse Responses to a U.S. Credit Shock
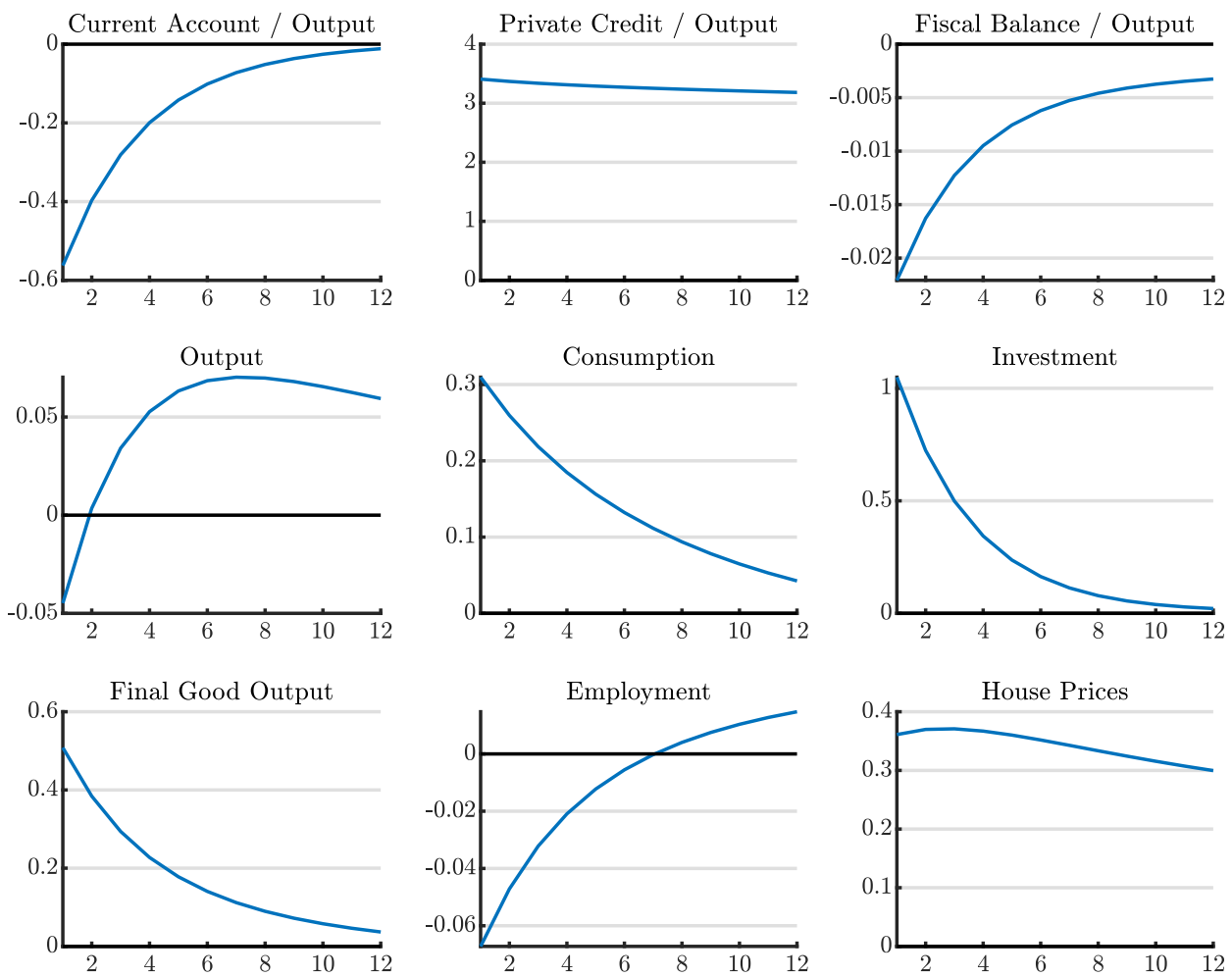

Figure 4: Impulse Responses to a U.S. Fiscal Shock
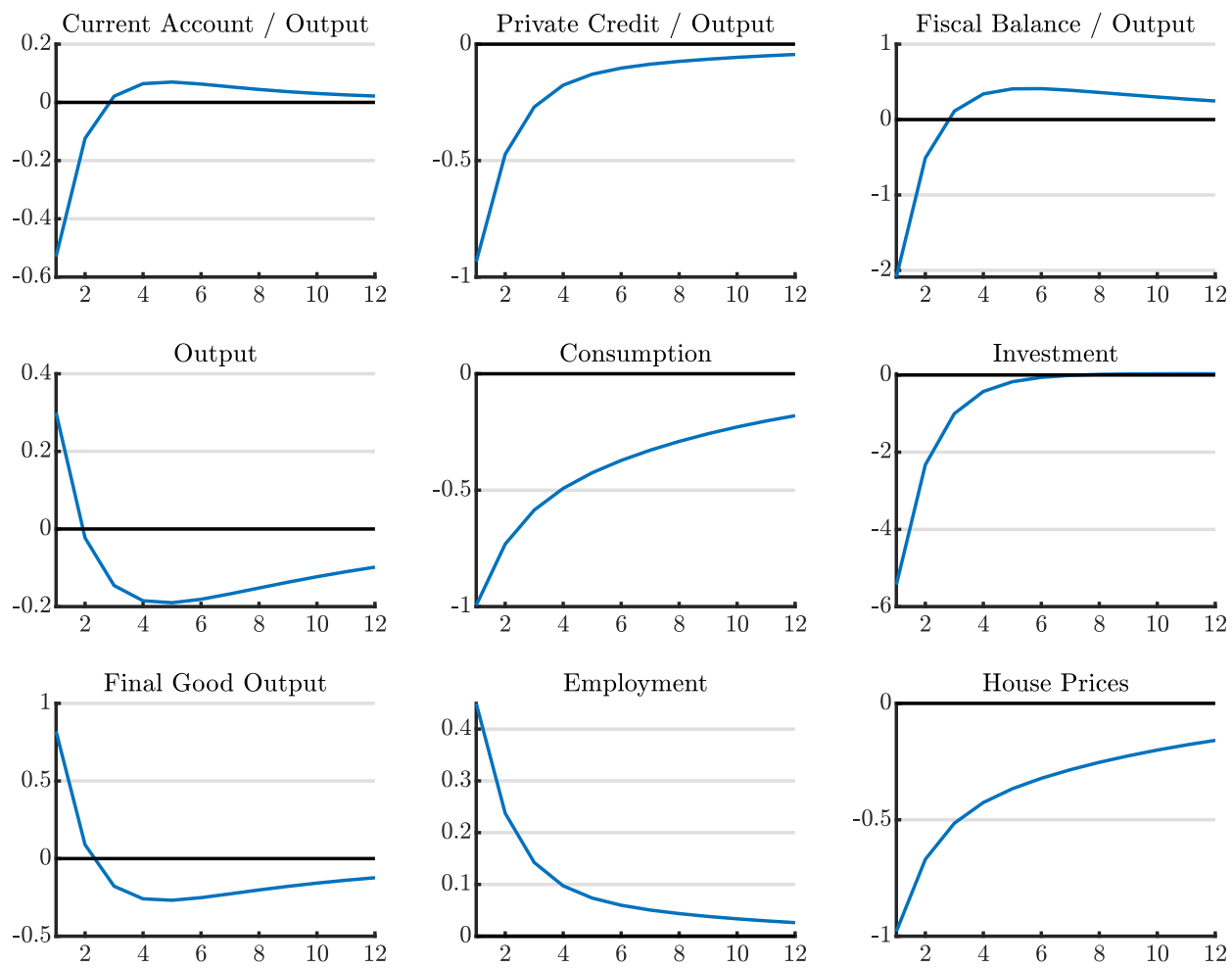
Figure 5: Impulse Responses to a U.S. Productivity Shock
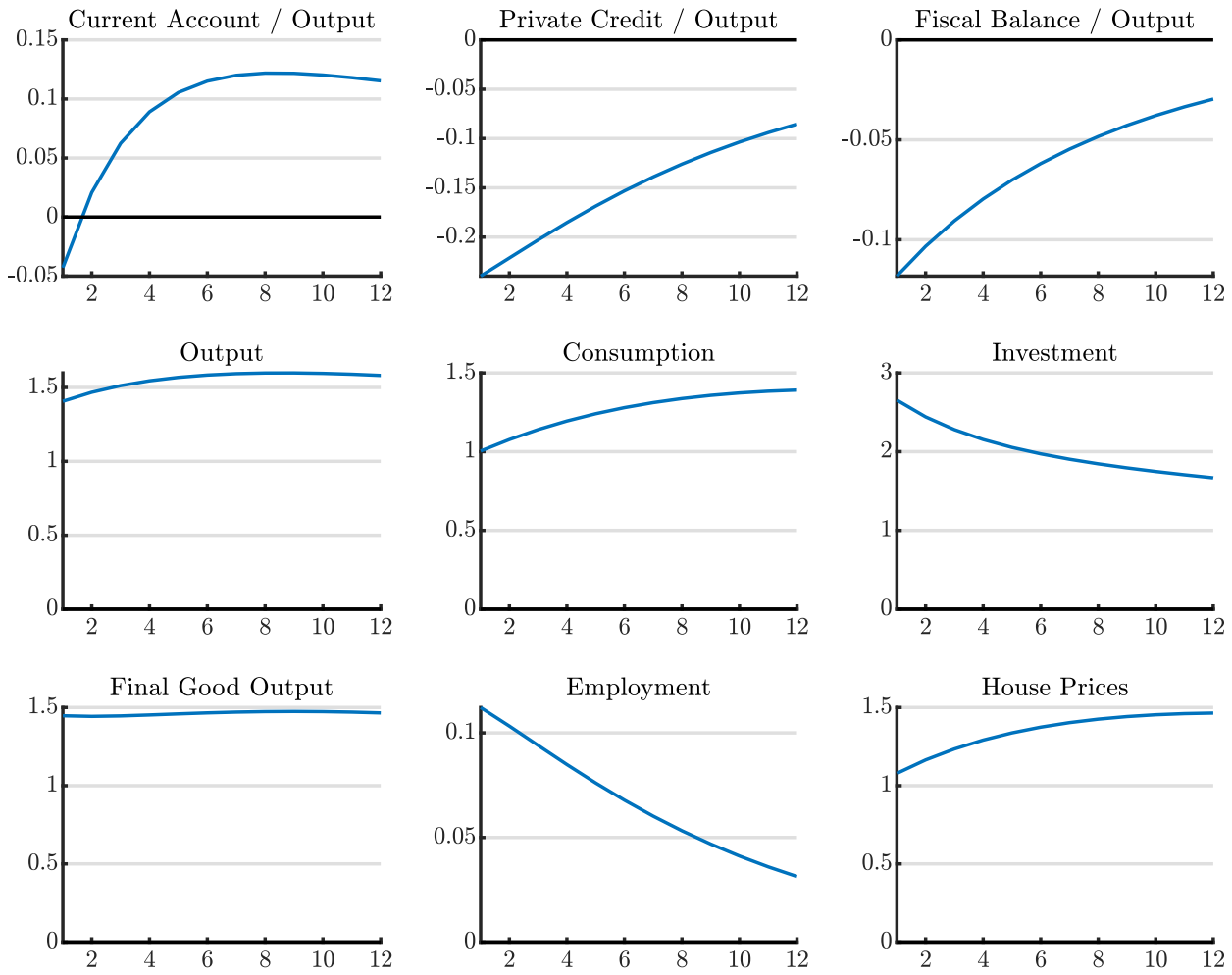

literature). The fiscal multiplier on output (intermediate goods production) is about 0.15 on impact, while the multiplier on final goods production is about 0.35 . These multipliers are smaller than the available estimates in the literature on the effects of government spending on GDP (see the survey in Ramey, 2011). While our model includes financial frictions, it does not include other features such as hand-to-mouth consumers, nominal rigidities, a weak response of monetary policy to inflation, and labor market frictions that are key to generate large fiscal multipliers in DSGE models (see Galí et al., 2007).

Finally, Figure 5 presents the responses to an increase in U.S. productivity. In this case, the current account moves to deficit on impact but quickly switches to a surplus because increased production leads to higher exports than imports. Private credit increases to take advantage of the investment opportunities that arise with high productivity, but the private credit-to-GDP ratio declines because of the large expansion in output. Finally, the fiscal balance moves to deficit due to the estimated fiscal rule: the increase in output leads to a decline in the government debt-GDP ratio, which in turns triggers a lump-sum tax cut that temporarily lowers government revenue. This also helps in explaining the comovement between the current account and the 
fiscal balance.

\subsection{Role of $\alpha$ in Estimated Model}

In this subsection, we explore what features of the data help to identify $\alpha$, the degree of idiosyncratic uncertainty, which is key in governing the impact of credit shocks on real variables. We report in Table 8 how changes in credit correlate with the current account for different values of $\alpha$, holding fixed the other parameters at their estimated values. The first column reports these correlations in the data, while the second through fourth columns report their correlations at our estimated value of $\alpha=2.3$ and for higher values of $\alpha$.

Table 8: Moments Across $\alpha$

\begin{tabular}{lcccc}
\hline Correlation & U.S. Data & $\alpha=2.3$ & $\alpha=4$ & $\alpha=8$ \\
\hline Current Account, $\Delta$ Credit & -0.44 & -0.29 & -0.07 & 0.06 \\
\hline
\end{tabular}

As the table shows, with higher values of $\alpha$, the correlation between the current account changes sign, from -0.29 at our estimated value to 0.06 at $\alpha=8$. This is because, with lower $\alpha$, the degree of idiosyncratic uncertainty increases, and the household values more liquid savings so as to smooth the marginal utilities of consumption across its members within each period. In response to a shock that reduces the availability of credit, the household finds it optimal to maintain its liquid asset holdings and instead cut consumption and imports. This generates the comovement between the current account and changes in credit that are observed in the data. When the degree of idiosyncratic uncertainty is low ( $\alpha$ is high), changes in credit have little effect, because the household prefers to use its liquid savings to smooth consumption intertemporally. In this case, the model cannot match the current account and household credit comovement.

\section{Credit Shocks, Fiscal Policy and the Current Account}

As the variance decomposition (Table 7) shows, credit shocks are an important driver of the current account while fiscal shocks explain a non-trivial amount of the variation in current 
Figure 6: U.S. Current Account to GDP, Counterfactuals
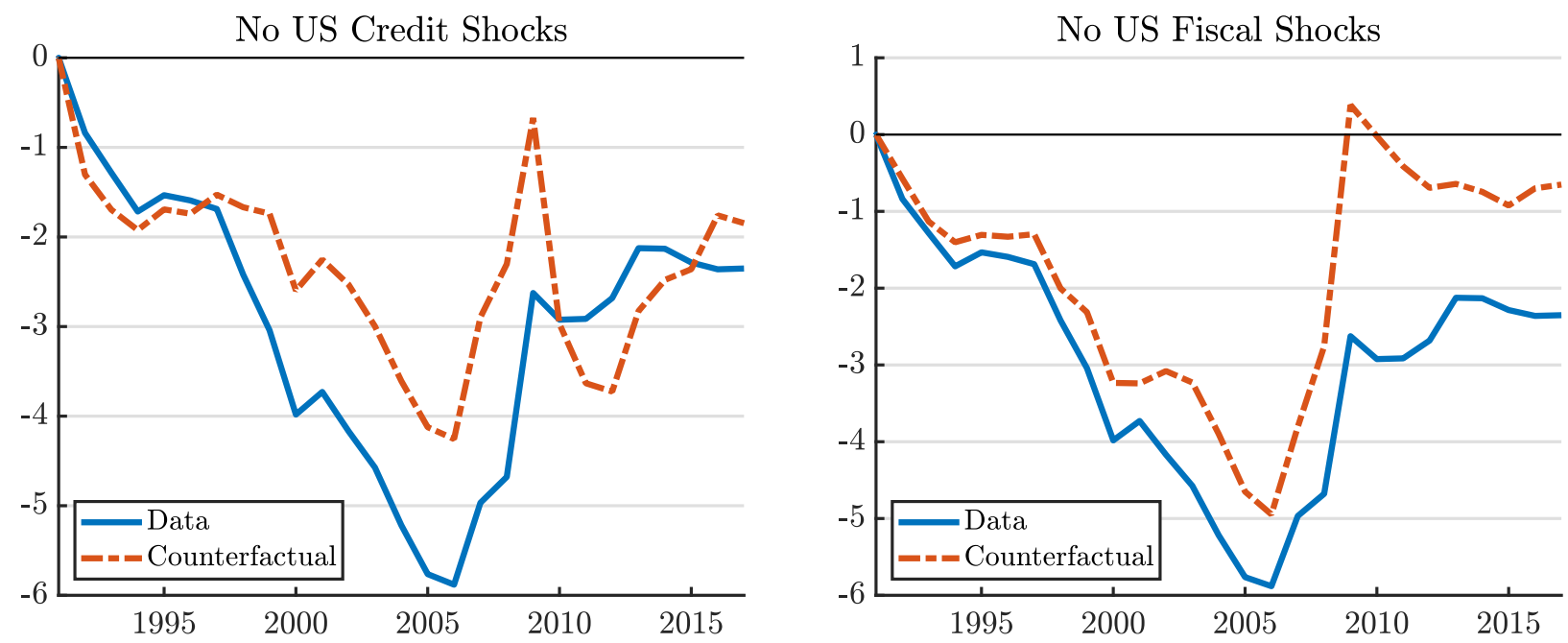

account. We next use our model to explore counterfactual series constructed without U.S. credit and fiscal shocks to study how global imbalances would have evolved absent these forces. Motivated by these counterfactual series, we then explore alternative U.S. macroprudential and fiscal policy rules that alleviate the impact of domestic shocks and study implications for the extent of global imbalances. In this section, we use the law of motion of the model implied by the parameter estimates of Tables 3 and 4 and the seven macroeconomic time series to apply standard Kalman smoother equations as in Harvey (1989) to extract the structural shocks of the model. ${ }^{14}$

\subsection{The Role of U.S. Credit and Fiscal Shocks}

In this subsection, we present two counterfactuals for the U.S. current account balance, one where we remove the estimated U.S. credit shocks and another where we remove U.S. fiscal shocks. This exercises allows us to understand what has been the role of these two shocks in shaping up the U.S. current account over the last three decades.

Figure 6 shows the U.S. current account-to-GDP ratio in the two experiments. In the first, plotted in the left panel, we remove U.S. credit shocks from 1991 onwards, that is, following the 1990 recession when the U.S. current account was roughly in balance. Absent U.S. credit

\footnotetext{
${ }^{14}$ As explained in Section 4, since the model has six shocks and we are using seven macroeconomic time series, we included a measurement error shock in the ROW output growth measurement equation to avoid singularity issues.
} 
shocks over this period, the U.S. current account-to-GDP ratio would have fallen to -4 percent at its lowest, compared to the almost -6 percent observed at the trough in 2006 . Absent the tightening of credit from 2008 to 2013, the current account-to-GDP ratio would have expanded from about -1 percent to almost $-3^{1 / 2}$ percent, larger than the actual value above -3 percent in 2013. The tightening of credit thus contributed to a significant reversal in the U.S. current account deficit in the aftermath of the Great Recession. Interestingly, towards the end of our sample (2017), we find that credit shocks were again leading to a larger U.S. current account deficit.

We plot in the right panel of Figure 6 the U.S. current account balance in a counterfactual where fiscal shocks are removed from 1991 onwards. Fiscal policy was mildly expansionary over the 1991 to 2006 period, and absent fiscal shocks over this period, the U.S. current account-toGDP ratio would have fallen to about -4.8 percent, just over 1 percentage point more positive than observed in 2006. The more significant U.S. fiscal expansion during the 2008-09 recession contributed, by themselves, to about 3 percentage points of the U.S. current account-to-GDP deficit. Removing fiscal shocks over this period would have seen the current account turn positive in 2009 (at about 0.6 percent) and remain close to balance until the end of our sample.

\subsection{Macroprudential Policies}

We next consider the role of macroprudential policies, implemented in the following way:

$$
q_{t} l_{t} \leq \text { macropru }_{t} m_{t} e_{t} h_{t+1}
$$

The trivial case is for macroprudential policy that perfectly offsets $m_{t}$ shocks. More realistically, we consider macroprudential instruments that are implemented as simple feedback rules, responding to lagged credit conditions or deviations of house prices from equilibrium levels. To parameterize these rules, we use the utility function (up to second order) and search over a parameter grid to assign optimal coefficients. ${ }^{15}$ We assume for simplicity that the U.S. regulator

\footnotetext{
${ }^{15}$ The welfare function is given in the Appendix.
} 
focuses on U.S. welfare taking ROW as given. ${ }^{16}$

We explore two macroprudential rules in our framework. The first rule is one that responds to the credit shock innovation in the previous year:

$$
\text { macropru }_{t}=1-\phi_{m} \varepsilon_{m, t-1}
$$

The second rule is:

$$
\operatorname{macropru}_{t}=1-\phi_{m}\left(\frac{e_{t-1}}{e}-1\right)
$$

or a rule that tightens credit as lagged house prices rise relative to their steady-state value. In our counterfactuals, we extract the model's shocks where macroprudential policy is turned off, impose the candidate macroprudential rule and simulate the economy under those shocks.

In the experiment with the macroprudential rule (34), the optimal value for the response is about $\phi_{m}=0.8 .{ }^{17}$ The counterfactual series is shown in Figure 7. In line with the results presented in Figure 6 in which we removed U.S. credit shocks, macroprudential policy in this case would work to ameliorate the impact of changes in credit. The debt-to-income ratio would not have increased by the 49 percentage points observed between 1997 and 2008, and would instead have increased by 41 percentage points by 2008. The current account-to-GDP balance would not have fallen by the same amount as observed under this macroprudential policy and would have been smaller by almost 0.4 percentage points by 2007 . GDP would not have changed much, reflecting the relatively small role that credit shocks have in explaining aggregate output in our estimated model.

We next consider the simulation of the model under the macroprudential rule that responds to deviations of house prices from their steady-state value, that is the rule in equation (35). Under this policy, the welfare-maximizing value of the reaction in the macroprudential rule is $\phi_{m}=8.4$, which implies a very strong reaction of policy to deviations of house prices from their steady-state value, to offset the impact of credit shocks. As we document in the Appendix, we

\footnotetext{
${ }^{16}$ The qualitative results in this section would also apply if the ROW policymakers conducted similar countercyclical policies. However, we recognize that the ROW is an aggregate of several economies that would have to conduct that same policy in a coordinated way.

${ }^{17}$ We show how the welfare function varies over $\phi_{m}$ for the different rules in the Appendix.
} 
Figure 7: Macroprudential Rule Responding to Household Credit Shocks
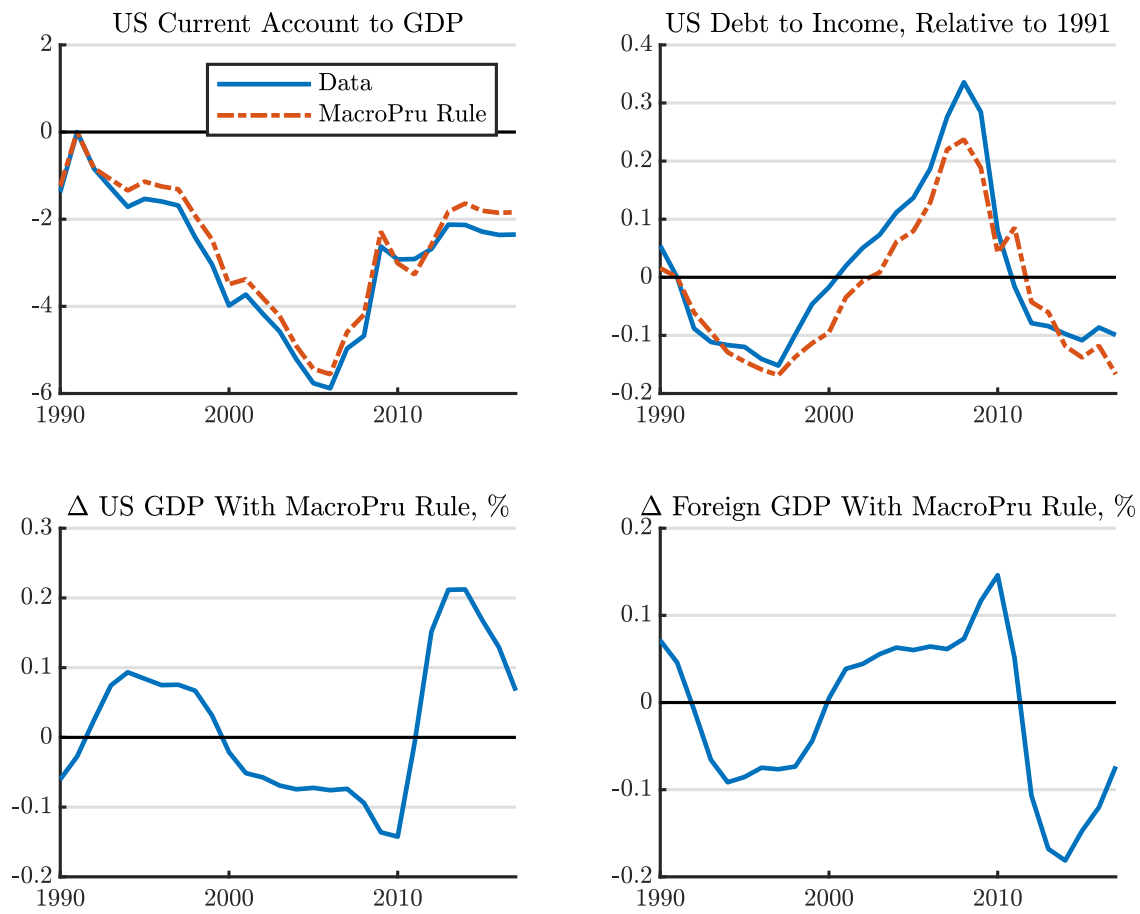

Figure 8: Macroprudential Rule Responding to House Price Fluctuations
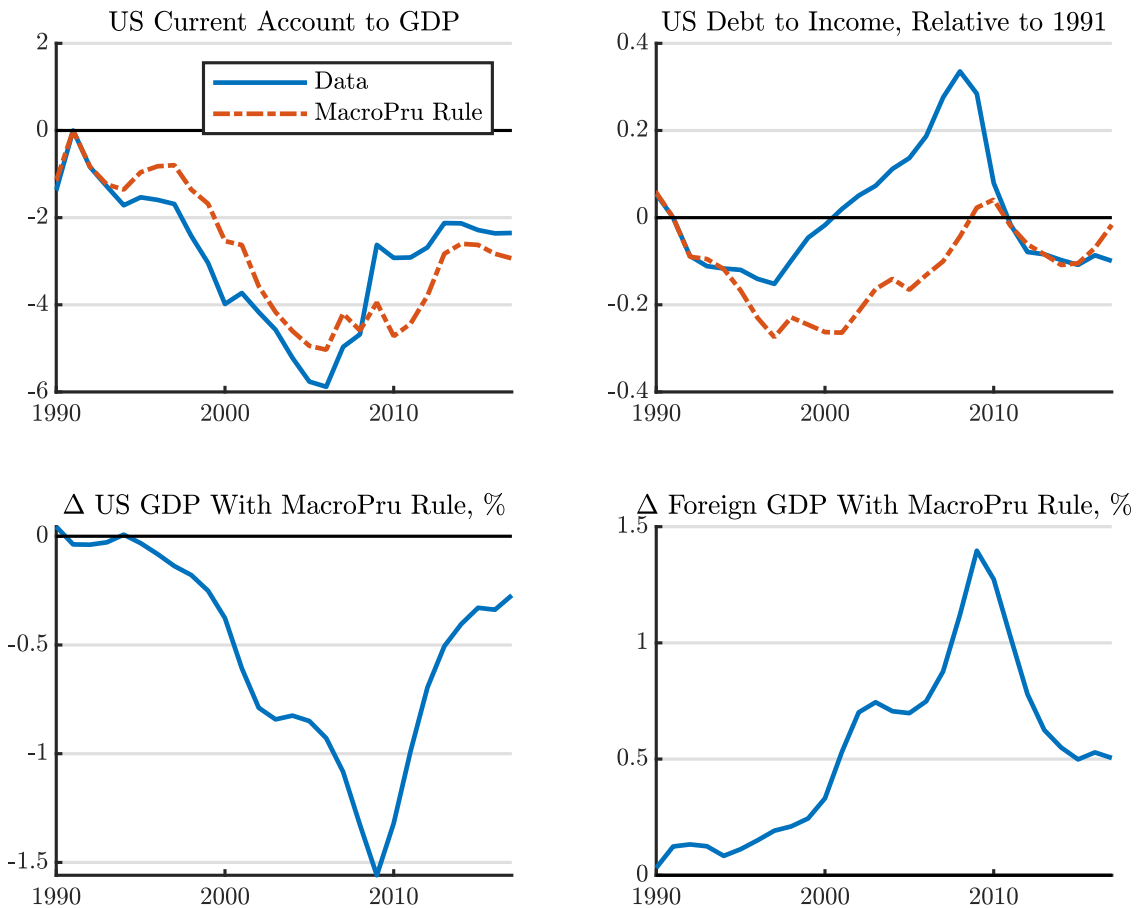
found that a rule with this coefficient would generate implausibly large fluctuations in debtto-income. In light of these observations, we instead use a value of $\phi_{m}=2$ for illustrative purposes. Figure 8 plots the counterfactual paths of observable variables in our model. Under the macroprudential rule, debt-to-income would have been much flatter between 1997 and 2008. Instead of gradually rising through 2000 to 2007, comoving with the increase in house prices, the debt-to-income ratio would have stayed below its 1991 level up to 2008. Furthermore, macroprudential policy in this case would have expanded the availability of credit from 2008 onwards relative to the path observed, leading to a much smaller decline in the debt-to-income ratio after 2008 in the experiment. This in turn would have supported consumption and investment, leading to a faster recovery and a more negative current account balance.

\subsection{Fiscal Policy}

We next study alternative settings of fiscal policy and how they can influence the dynamics of debt, GDP, and the current account. Recall that in our baseline specification, government spending adjusts in line with changes in output, subject to an autoregressive innovation. We study a fiscal rule in which government spending responds to the lagged value of output growth:

$$
g_{t}=\frac{g}{Y} Y_{t}-\phi_{g} \log \frac{y_{t-1}}{y_{t-2}}+\xi_{g, t}
$$

where $\phi_{g}$ parameterizes the extent to which government spending leans against output growth. Optimal policy yields a value of $\phi_{g}=2.1$, as we report in the Appendix.

Figure 9 plots the paths of the variables under the fiscal rule (36) parameterized at its optimal value. Under this setting of fiscal policy, the current account deficit would contract while the path of debt-to-income is little changed. In general, a more countercyclical fiscal policy would have lowered the U.S. current account deficit over most of the time period considered, as it would have withdrawn domestic demand in periods where the economy was growing. The main exception to this pattern is during the Great Recession, where GDP in the U.S. would have benefitted from fiscal policy offsetting the large negative growth rate observed in 2009: in this period, the current account deficit would have been somewhat larger. 
Figure 9: Fiscal Rule Responding to Lagged Output Growth
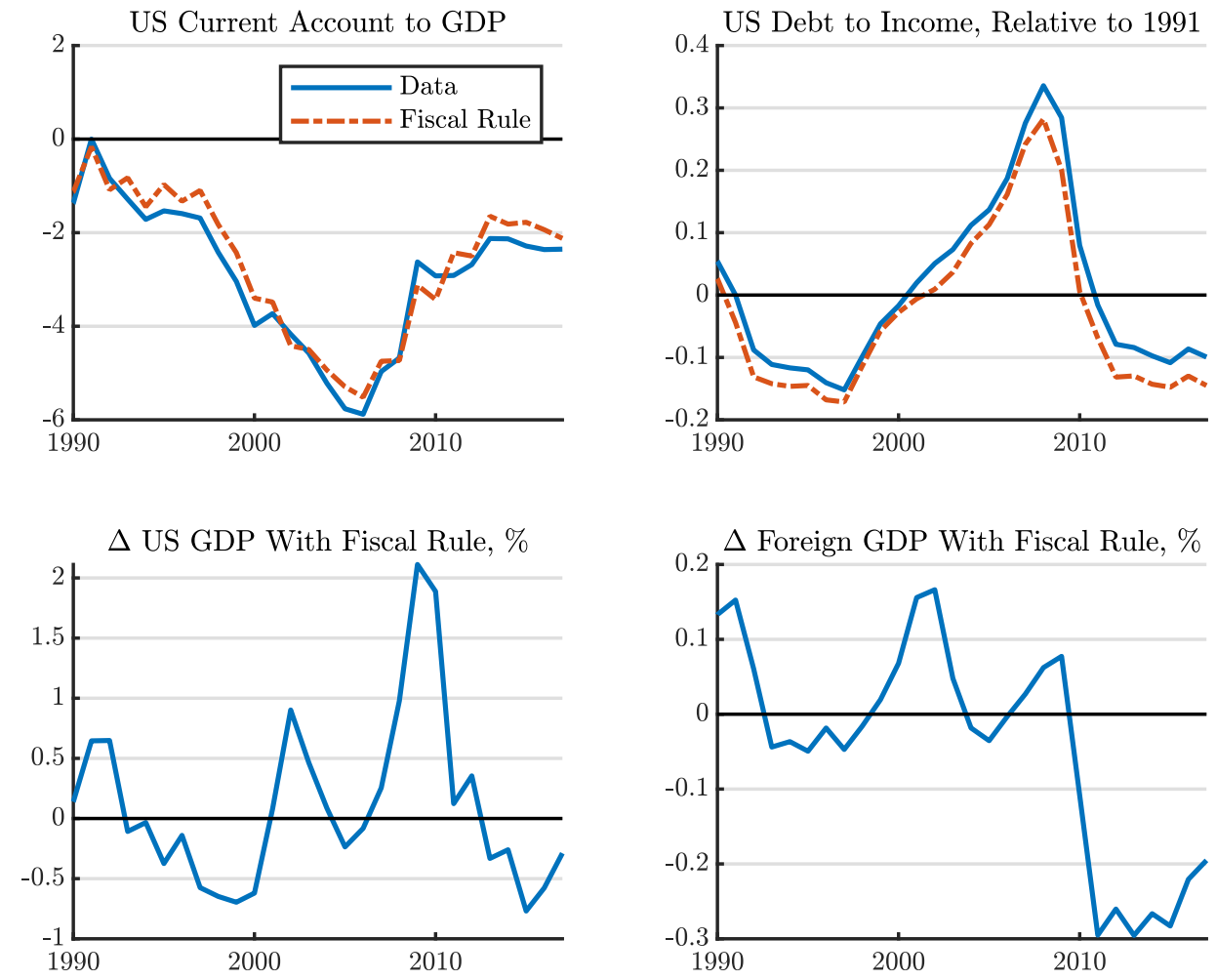

Figure 10: Fiscal Balance Under Rule Responding to Lagged Output Growth

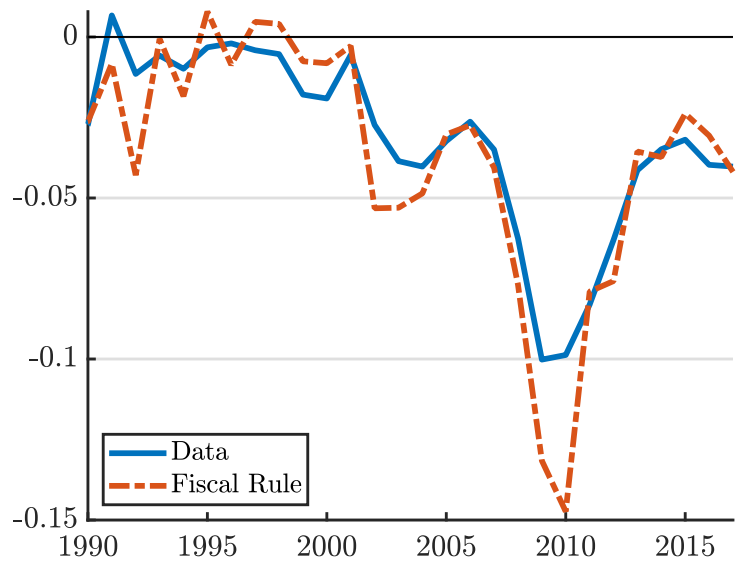

Figure 10 plots the fiscal balance in the data and in the counterfactual under the rule, which shows that during recessions the fiscal rule would have lead to larger fiscal deficits, including during the 2009 to 2010 period, where the U.S. fiscal deficit would have been more negative by 4 to 5 percentage points. This rule would have called for faster fiscal consolidation in the boom years of 1996-2000, and towards the end of the sample period considered (2016-2017). 


\section{Conclusion}

This paper has shown that there is a strong link between credit cycles, fiscal policies and global imbalances. Using a sample of 38 advanced and emerging economies, we have shown that the credit cycle has an important impact on a country's currency account: when credit increases, the current account deteriorates; when credit declines, the current account improves. We have also confirmed the results for the "twin deficits" literature, in the sense that the fiscal and current account balances comove positively in the data.

To dig deeper into these relationships for the case of the U.S., we have used an estimated two-country DSGE model with credit, financial frictions and fiscal policy and analyzed the role of credit, productivity and government spending shocks. The model is estimated using a Generalized Method of Moments methodology that aims at matching particular features of the data that we are interested in, such as the comovement between credit, fiscal policy, and the current account. Our findings suggest that credit market shocks are a main driver of the U.S. current account, with about roughly 30 percent of the volatility of the U.S current account driven by domestic credit market shocks and another one-third driven by foreign credit market shocks. U.S. fiscal shocks explain about 13.9 percent of the U.S. current account volatility. We have shown that absent these domestic shocks, the level and volatility of the U.S. current account deficit would have been smaller during the last three decades. In the last part of the paper, we have shown how U.S. macroprudential policy rules that aim at stabilizing the domestic credit

cycle, and U.S. fiscal policy rules that aim at stabilizing the business cycle, would also help in lowering the level and volatility of the U.S. current account. This result is important because it shows how policies that have domestic objectives have implications for global imbalances. 


\section{References}

Abbas, S. M. A., Bounga-Hagbe, J., Fatás, A., Mauro, P. and Velloso, R. C. (2011). Fiscal Policy and the Current Account. IMF Economic Review, 59 (4), 603-629.

Adam, K., Kuang, P. and Marcet, A. (2011). House Price Booms and the Current Account. Working Paper 17224, National Bureau of Economic Research.

Andreasen, M. M., Fernandez-Villaverde, J. and Rubio-Ramirez, J. F. (2018). The pruned state-space system for non-linear dsge models: Theory and empirical applications. Review of Economic Studies, 85 (1), 1-49.

Bartolini, L. and LAhiri, A. (2006). Twin deficits, twenty years later. Current Issues in Economics and Finance, 12 (Oct).

Cavallo, M. (2005). Understanding the twin deficits: new approaches, new results. FRBSF Economic Letter, (jul22), 16.

Cesa-Bianchi, A., Ferrero, A. and Rebucci, A. (2018). International credit supply shocks. Journal of International Economics, 112 (C), 219-237.

Chinn, M. D., Eichengreen, B. and Ito, H. (2014). A forensic analysis of global imbalances. Oxford Economic Papers, 66 (2), 465-490.

— and PrASAD, E. S. (2003). Medium-term determinants of current accounts in industrial and developing countries: an empirical exploration. Journal of International Economics, 59 (1), 47-76.

Coutinho, L., Turrini, A. and Zeugner, S. (2018). Methodologies for the Assessment of Current Account Benchmarks. European Economy - Discussion Papers 2015 - 086, Directorate General Economic and Financial Affairs (DG ECFIN), European Commission, Brussels, Belgium.

Cubeddu, L. M., Krogstrup, S., Adler, G., Rabanal, P., Dao, M. C., Hannan, S. A., Juvenal, L., Buitron, C. O., Rebillard, C., Garcia-Macia, D., Jones, C., 
Rodriguez, J., Chang, K. S., Gautam, D., Wang, Z. and Li, N. (2019). The External Balance Assessment Methodology: 2018 Update. IMF Working Paper 19/65, International Monetary Fund.

Dell'Ariccia, G., Igan, D., Laeven, L. and Tong, H. (2016). Credit booms and macrofinancial stability. Economic Policy, 31 (86), 299-355.

Drehmann, M., Borio, C. and Tsatsaronis, K. (2011). Anchoring Countercyclical Capital Buffers: The Role of Credit Aggregates. International Journal of Central Banking, 7 (4), 189240.

Ferrero, A. (2015). House Price Booms, Current Account Deficits, and Low Interest Rates. Journal of Money, Credit and Banking, 47 (S1), 261-293.

Galí, J., Lopez-Salido, D. and Valles, J. (2007). Understanding the effects of government spending on consumption. Journal of the European Economic Association, 5 (1), 227-270.

Gourinchas, P.-O., Valdés, R. and Landerretche, O. (2001). Lending booms: Latin america and the world. Working Paper 8249, National Bureau of Economic Research.

Gruber, J. W. and Kamin, S. B. (2007). Explaining the global pattern of current account imbalances. Journal of International Money and Finance, 26 (4), 500-522.

Harvey, A. C. (1989). Forecasting, Structural Time Series Models and the Kalman Filter. Cambridge University Press.

Heathcote, J. and Perri, F. (2002). Financial autarky and international business cycles. Journal of Monetary Economics, 49 (3), 601-627.

— and - (2016). On the Desirability of Capital Controls. IMF Economic Review, 64 (1), $75-102$.

IACOviello, M. (2005). House prices, borrowing constraints, and monetary policy in the business cycle. American Economic Review, 95 (3), 739-764. 
Imbs, J. and Mejean, I. (2015). Elasticity optimism. American Economic Journal: Macroeconomics, 7 (3), 43-83.

International Monetary Fund (2019). 2019 External Sector Report: The dynamics of external adjustment. International Monetary Fund, Washington D.C.

International Monetary Fund (2020). 2020 External Sector Report: Global imbalances and the COVID-19 crisis. International Monetary Fund, Washington D.C.

Jones, C., Midrigan, V. and Philippon, T. (2020). Household Leverage and the Recession. mimeo.

Mendoza, E. G. and Terrones, M. E. (2012). An Anatomy of Credit Booms and their Demise. Working Paper 18379, National Bureau of Economic Research.

Mian, A., Rao, K. and Sufi, A. (2013). Household balance sheets, consumption, and the economic slump. The Quarterly Journal of Economics, 128 (4), 1687-1726.

— and Sufi, A. (2011). House prices, home equity-based borrowing, and the u.s. household leverage crisis. American Economic Review, 101 (5), 2132-2156.

— and - (2014). What explains the 2007-2009 drop in employment? Quarterly Journal of Economics, 82 (6), 2197-2223.

RAmey, V. A. (2011). Can government purchases stimulate the economy? Journal of Economic Literature, 49 (3), 673-85.

Turrini, A. and Zeugner, S. (2019). Benchmarks for net international investment positions. Journal of International Money and Finance, 95 (C), 149-164. 


\section{A Additional Tables}

Tables A.1 to A.3 provide additional empirical results on the correlation between credit-to-GDP and the current account and different horizons. 
Table A.1: Correlation Between $1 Y \Delta$ in Credit-to-GDP at $\mathrm{t}+\mathrm{k}$ and the Current Account at $\mathrm{t}$

\begin{tabular}{|c|c|c|c|c|c|c|c|}
\hline Country $\backslash \mathrm{k}$ & -3 & -2 & -1 & 0 & 1 & 2 & 3 \\
\hline Argentina & 0.00 & -0.20 & -0.37 & -0.17 & -0.02 & -0.17 & -0.14 \\
\hline Australia & 0.22 & 0.07 & -0.12 & -0.48 & -0.46 & -0.25 & -0.19 \\
\hline Austria & -0.12 & -0.14 & -0.11 & -0.07 & 0.02 & -0.02 & -0.06 \\
\hline Belgium & -0.10 & -0.04 & 0.02 & -0.31 & -0.08 & -0.08 & -0.10 \\
\hline Brazil & 0.02 & 0.06 & 0.25 & 0.17 & -0.10 & -0.22 & -0.03 \\
\hline Canada & -0.08 & 0.01 & 0.01 & -0.29 & -0.41 & -0.37 & -0.40 \\
\hline Chile & -0.28 & -0.11 & -0.06 & -0.55 & -0.40 & -0.06 & -0.23 \\
\hline China & 0.17 & 0.17 & 0.05 & -0.21 & -0.42 & -0.49 & -0.30 \\
\hline Colombia & 0.11 & -0.02 & -0.42 & -0.63 & -0.61 & -0.36 & -0.29 \\
\hline Czech Republic & 0.08 & 0.26 & 0.15 & 0.05 & 0.31 & 0.45 & 0.40 \\
\hline Denmark & -0.07 & -0.09 & -0.20 & -0.28 & -0.24 & -0.21 & -0.08 \\
\hline Finland & 0.29 & 0.15 & -0.05 & -0.22 & -0.31 & -0.41 & -0.38 \\
\hline France & -0.14 & -0.16 & -0.38 & -0.49 & -0.55 & -0.52 & -0.62 \\
\hline Germany & -0.19 & -0.23 & -0.28 & -0.35 & -0.42 & -0.45 & -0.41 \\
\hline Greece & -0.64 & -0.69 & -0.72 & -0.73 & -0.67 & -0.49 & -0.33 \\
\hline Hungary & -0.73 & -0.64 & -0.60 & -0.49 & -0.28 & -0.01 & 0.11 \\
\hline India & 0.56 & 0.46 & 0.32 & 0.08 & 0.19 & -0.05 & -0.14 \\
\hline Indonesia & 0.12 & 0.03 & -0.27 & -0.44 & -0.53 & -0.48 & -0.39 \\
\hline Ireland & 0.53 & 0.20 & -0.09 & -0.41 & -0.49 & -0.61 & -0.65 \\
\hline Italy & -0.01 & -0.28 & -0.61 & -0.74 & -0.79 & -0.73 & -0.61 \\
\hline Korea & 0.22 & -0.02 & -0.47 & -0.41 & 0.00 & 0.10 & -0.01 \\
\hline Japan & 0.07 & 0.32 & 0.38 & 0.00 & -0.11 & -0.25 & -0.49 \\
\hline Malaysia & -0.09 & -0.28 & -0.51 & -0.59 & -0.47 & -0.26 & -0.23 \\
\hline Mexico & 0.49 & 0.32 & 0.08 & -0.44 & -0.64 & -0.61 & -0.55 \\
\hline Netherlands & -0.01 & -0.21 & -0.39 & -0.31 & -0.14 & -0.11 & -0.12 \\
\hline Norway & 0.36 & 0.44 & 0.34 & 0.06 & -0.02 & 0.19 & 0.43 \\
\hline Peru & -0.01 & -0.06 & -0.30 & -0.50 & -0.43 & -0.36 & -0.25 \\
\hline Poland & -0.24 & -0.32 & -0.20 & -0.44 & -0.52 & -0.46 & -0.02 \\
\hline Portugal & -0.35 & -0.59 & -0.63 & -0.66 & -0.57 & -0.50 & -0.35 \\
\hline Russia & 0.36 & 0.32 & 0.13 & -0.10 & 0.09 & 0.09 & -0.20 \\
\hline South Africa & 0.27 & 0.23 & 0.05 & -0.22 & -0.25 & -0.09 & 0.09 \\
\hline Spain & -0.21 & -0.42 & -0.66 & -0.83 & -0.91 & -0.83 & -0.66 \\
\hline Sweden & 0.39 & 0.42 & 0.38 & 0.23 & 0.14 & 0.02 & -0.08 \\
\hline Switzerland & 0.15 & 0.02 & -0.38 & -0.34 & 0.04 & -0.10 & -0.07 \\
\hline Thailand & -0.18 & -0.44 & -0.70 & -0.69 & -0.46 & -0.28 & -0.11 \\
\hline Turkey & -0.55 & -0.54 & -0.50 & -0.78 & -0.63 & -0.49 & -0.59 \\
\hline United Kingdom & 0.47 & 0.33 & 0.22 & 0.11 & 0.15 & 0.30 & 0.20 \\
\hline United States & 0.07 & -0.18 & -0.46 & -0.51 & -0.48 & -0.46 & -0.45 \\
\hline Full sample, Mean & 0.03 & -0.05 & -0.19 & -0.34 & -0.30 & -0.25 & -0.22 \\
\hline Full sample, Median & 0.01 & -0.03 & -0.20 & -0.38 & -0.40 & -0.25 & -0.21 \\
\hline AEs, Mean & 0.04 & -0.04 & -0.18 & -0.32 & -0.27 & -0.24 & -0.23 \\
\hline AEs, Median & 0.03 & -0.03 & -0.16 & -0.33 & -0.27 & -0.25 & -0.26 \\
\hline EMDEs, Mean & 0.00 & -0.07 & -0.19 & -0.37 & -0.34 & -0.27 & -0.21 \\
\hline EMDEs, Median & 0.01 & -0.04 & -0.24 & -0.44 & -0.42 & -0.27 & -0.21 \\
\hline
\end{tabular}

Sources: IMF World Economic Outlook database, Bank for International Settlements, World Development Indicators and authors' calculations. 
Table A.2: Correlation Between 2Y $\Delta$ in Credit-to-GDP at $\mathrm{t}+\mathrm{k}$ and the Current Account at $\mathrm{t}$

\begin{tabular}{|c|c|c|c|c|c|c|c|}
\hline Country \k & -3 & -2 & -1 & 0 & 1 & 2 & 3 \\
\hline Argentina & -0.18 & -0.50 & -0.47 & -0.17 & -0.17 & -0.28 & -0.20 \\
\hline Australia & 0.16 & 0.00 & -0.30 & -0.55 & -0.42 & -0.23 & -0.20 \\
\hline Austria & -0.16 & -0.15 & -0.10 & -0.03 & 0.01 & -0.05 & -0.14 \\
\hline Belgium & -0.15 & -0.05 & -0.27 & -0.32 & -0.12 & -0.14 & -0.14 \\
\hline Brazil & 0.04 & 0.21 & 0.29 & 0.07 & -0.18 & -0.14 & -0.01 \\
\hline Canada & -0.05 & 0.01 & -0.21 & -0.51 & -0.57 & -0.57 & -0.50 \\
\hline Chile & -0.26 & -0.11 & -0.40 & -0.60 & -0.29 & -0.18 & -0.35 \\
\hline China & 0.22 & 0.13 & -0.14 & -0.42 & -0.60 & -0.52 & -0.31 \\
\hline Colombia & 0.04 & -0.28 & -0.59 & -0.73 & -0.56 & -0.36 & -0.36 \\
\hline Czech Republic & 0.23 & 0.28 & 0.13 & 0.24 & 0.50 & 0.57 & 0.58 \\
\hline Denmark & -0.07 & -0.16 & -0.24 & -0.29 & -0.25 & -0.16 & 0.02 \\
\hline Finland & 0.28 & 0.06 & -0.17 & -0.33 & -0.45 & -0.49 & -0.50 \\
\hline France & -0.17 & -0.31 & -0.51 & -0.61 & -0.64 & -0.69 & -0.69 \\
\hline Germany & -0.35 & -0.39 & -0.46 & -0.52 & -0.59 & -0.58 & -0.50 \\
\hline Greece & -0.76 & -0.81 & -0.84 & -0.82 & -0.68 & -0.48 & -0.29 \\
\hline Hungary & -0.77 & -0.68 & -0.60 & -0.45 & -0.18 & 0.05 & 0.17 \\
\hline India & 0.62 & 0.48 & 0.23 & 0.17 & 0.09 & -0.12 & -0.34 \\
\hline Indonesia & 0.08 & -0.15 & -0.44 & -0.59 & -0.61 & -0.53 & -0.41 \\
\hline Ireland & 0.45 & 0.06 & -0.31 & -0.49 & -0.60 & -0.69 & -0.68 \\
\hline Italy & -0.14 & -0.46 & -0.71 & -0.82 & -0.82 & -0.73 & -0.58 \\
\hline Japan & 0.23 & 0.40 & 0.14 & -0.10 & -0.22 & -0.43 & -0.49 \\
\hline Korea & 0.14 & -0.31 & -0.55 & -0.24 & 0.09 & 0.05 & -0.03 \\
\hline Malaysia & -0.22 & -0.46 & -0.65 & -0.61 & -0.42 & -0.28 & -0.30 \\
\hline Mexico & 0.41 & 0.22 & -0.18 & -0.59 & -0.69 & -0.65 & -0.59 \\
\hline Netherlands & -0.14 & -0.39 & -0.45 & -0.29 & -0.16 & -0.15 & -0.20 \\
\hline Norway & 0.51 & 0.48 & 0.30 & 0.07 & 0.15 & 0.42 & 0.58 \\
\hline Peru & -0.05 & -0.19 & -0.45 & -0.52 & -0.46 & -0.32 & -0.24 \\
\hline Poland & -0.31 & -0.29 & -0.35 & -0.54 & -0.55 & -0.27 & 0.14 \\
\hline Portugal & -0.53 & -0.68 & -0.72 & -0.69 & -0.60 & -0.49 & -0.31 \\
\hline Russia & 0.44 & 0.27 & 0.00 & -0.01 & 0.11 & -0.08 & -0.34 \\
\hline South Africa & 0.30 & 0.17 & -0.09 & -0.29 & -0.21 & 0.01 & 0.24 \\
\hline Spain & -0.31 & -0.55 & -0.77 & -0.90 & -0.90 & -0.78 & -0.63 \\
\hline Sweden & 0.48 & 0.47 & 0.38 & 0.24 & 0.12 & 0.00 & -0.09 \\
\hline Switzerland & 0.10 & -0.22 & -0.42 & -0.16 & -0.01 & -0.07 & -0.08 \\
\hline Thailand & -0.34 & -0.64 & -0.77 & -0.63 & -0.41 & -0.21 & -0.02 \\
\hline Turkey & -0.64 & -0.61 & -0.76 & -0.81 & -0.64 & -0.62 & -0.57 \\
\hline United Kingdom & 0.44 & 0.29 & 0.16 & 0.14 & 0.27 & 0.31 & 0.21 \\
\hline United States & -0.06 & -0.35 & -0.53 & -0.54 & -0.52 & -0.51 & -0.50 \\
\hline Full sample, Mean & -0.01 & -0.14 & -0.31 & -0.38 & -0.32 & -0.27 & -0.23 \\
\hline Full sample, Median & -0.05 & -0.16 & -0.37 & -0.47 & -0.41 & -0.28 & -0.30 \\
\hline AEs, Mean & 0.01 & -0.13 & -0.29 & -0.34 & -0.29 & -0.27 & -0.23 \\
\hline AEs, Median & -0.06 & -0.15 & -0.30 & -0.32 & -0.34 & -0.33 & -0.24 \\
\hline EMDEs, Mean & -0.04 & -0.15 & -0.34 & -0.42 & -0.36 & -0.28 & -0.22 \\
\hline EMDEs, Median & 0.00 & -0.17 & -0.42 & -0.53 & -0.41 & -0.28 & -0.31 \\
\hline
\end{tabular}

Sources: IMF World Economic Outlook database, Bank for International Settlements, World Development Indicators and authors' calculations. 
Table A.3: Correlation Between $3 \mathrm{Y} \Delta$ in Credit-to-GDP at $\mathrm{t}+\mathrm{k}$ and the Current Account at $\mathrm{t}$

\begin{tabular}{|c|c|c|c|c|c|c|c|}
\hline Country \k & -3 & -2 & -1 & 0 & 1 & 2 & 3 \\
\hline Argentina & -0.46 & -0.60 & -0.45 & -0.29 & -0.27 & -0.33 & -0.30 \\
\hline Australia & 0.09 & -0.15 & -0.45 & -0.56 & -0.35 & -0.23 & -0.21 \\
\hline Austria & -0.16 & -0.13 & -0.05 & -0.01 & -0.02 & -0.11 & -0.16 \\
\hline Belgium & -0.11 & -0.29 & -0.28 & -0.36 & -0.19 & -0.19 & -0.24 \\
\hline Brazil & 0.22 & 0.37 & 0.24 & -0.12 & -0.23 & -0.17 & -0.06 \\
\hline Canada & -0.04 & -0.15 & -0.40 & -0.63 & -0.70 & -0.63 & -0.56 \\
\hline Chile & -0.26 & -0.39 & -0.55 & -0.55 & -0.36 & -0.32 & -0.38 \\
\hline China & 0.20 & -0.04 & -0.36 & -0.65 & -0.68 & -0.55 & -0.26 \\
\hline Colombia & -0.22 & -0.48 & -0.74 & -0.72 & -0.55 & -0.40 & -0.24 \\
\hline Czech Republic & 0.26 & 0.23 & 0.26 & 0.43 & 0.55 & 0.64 & 0.68 \\
\hline Denmark & -0.09 & -0.21 & -0.26 & -0.30 & -0.22 & -0.08 & 0.15 \\
\hline Finland & 0.17 & -0.06 & -0.27 & -0.43 & -0.50 & -0.56 & -0.57 \\
\hline France & -0.28 & -0.43 & -0.60 & -0.68 & -0.74 & -0.74 & -0.73 \\
\hline Germany & -0.48 & -0.54 & -0.60 & -0.64 & -0.68 & -0.63 & -0.60 \\
\hline Greece & -0.83 & -0.87 & -0.87 & -0.78 & -0.62 & -0.41 & -0.19 \\
\hline Hungary & -0.77 & -0.67 & -0.56 & -0.35 & -0.10 & 0.09 & 0.17 \\
\hline India & 0.60 & 0.39 & 0.24 & 0.09 & 0.00 & -0.27 & -0.43 \\
\hline Indonesia & -0.07 & -0.32 & -0.59 & -0.69 & -0.66 & -0.54 & -0.41 \\
\hline Ireland & 0.31 & -0.14 & -0.43 & -0.60 & -0.69 & -0.73 & -0.75 \\
\hline Italy & -0.31 & -0.59 & -0.80 & -0.86 & -0.82 & -0.70 & -0.49 \\
\hline Japan & 0.33 & 0.19 & 0.00 & -0.20 & -0.36 & -0.44 & -0.46 \\
\hline Korea & -0.14 & -0.48 & -0.44 & -0.12 & 0.06 & 0.01 & -0.15 \\
\hline Malaysia & -0.40 & -0.63 & -0.70 & -0.58 & -0.42 & -0.35 & -0.43 \\
\hline Mexico & 0.32 & -0.04 & -0.50 & -0.68 & -0.70 & -0.65 & -0.51 \\
\hline Netherlands & -0.30 & -0.44 & -0.38 & -0.27 & -0.17 & -0.20 & -0.30 \\
\hline Norway & 0.58 & 0.51 & 0.32 & 0.21 & 0.38 & 0.61 & 0.63 \\
\hline Peru & -0.16 & -0.37 & -0.52 & -0.56 & -0.41 & -0.32 & -0.22 \\
\hline Poland & -0.31 & -0.39 & -0.47 & -0.58 & -0.42 & 0.02 & 0.18 \\
\hline Portugal & -0.62 & -0.74 & -0.73 & -0.70 & -0.58 & -0.44 & -0.23 \\
\hline Russia & 0.45 & 0.12 & 0.00 & 0.02 & -0.02 & -0.24 & -0.52 \\
\hline South Africa & 0.23 & 0.01 & -0.22 & -0.29 & -0.13 & 0.13 & 0.27 \\
\hline Spain & -0.43 & -0.68 & -0.86 & -0.92 & -0.87 & -0.74 & -0.59 \\
\hline Sweden & 0.55 & 0.51 & 0.40 & 0.25 & 0.12 & 0.01 & -0.06 \\
\hline Switzerland & -0.12 & -0.29 & -0.26 & -0.13 & 0.02 & -0.04 & -0.17 \\
\hline Thailand & -0.54 & -0.76 & -0.75 & -0.57 & -0.34 & -0.13 & 0.08 \\
\hline Turkey & -0.67 & -0.78 & -0.81 & -0.78 & -0.70 & -0.61 & -0.51 \\
\hline United Kingdom & 0.40 & 0.22 & 0.16 & 0.25 & 0.32 & 0.31 & 0.21 \\
\hline United States & -0.24 & -0.47 & -0.59 & -0.59 & -0.58 & -0.57 & -0.60 \\
\hline Full sample, Mean & -0.09 & -0.25 & -0.37 & -0.39 & -0.33 & -0.28 & -0.24 \\
\hline Full sample, Median & -0.13 & -0.30 & -0.44 & -0.55 & -0.36 & -0.32 & -0.25 \\
\hline AEs, Mean & -0.07 & -0.23 & -0.32 & -0.35 & -0.30 & -0.27 & -0.25 \\
\hline AEs, Median & -0.12 & -0.25 & -0.39 & -0.40 & -0.35 & -0.32 & -0.24 \\
\hline EMDEs, Mean & -0.11 & -0.29 & -0.42 & -0.46 & -0.38 & -0.29 & -0.22 \\
\hline EMDEs, Median & -0.19 & -0.38 & -0.51 & -0.57 & -0.39 & -0.32 & -0.28 \\
\hline
\end{tabular}

Sources: IMF World Economic Outlook database, Bank for International Settlements, World Development Indicators and authors' calculations. 


\section{B Equilibrium of the Model}

The equilibrium consists of the following equations for the home and foreign economies.

1) Consumption choices are optimized

$$
\begin{aligned}
& c_{t}(v)=\min \left[\frac{v}{\frac{\beta}{q_{t}} P_{t} \mathbb{E}_{t} \mu_{t+1}}, x_{t}\right] \\
& c_{t}^{*}(v)=\min \left[\frac{v}{\frac{\beta}{q_{t}} P_{t}^{*} \mathbb{E}_{t} \mu_{t+1}^{*}}, x_{t}^{*}\right]
\end{aligned}
$$

2) Funds allocated to the goods market are optimized

$$
\begin{aligned}
P_{t} \mu_{t} & =\frac{\beta}{q_{t}} P_{t} \mathbb{E}_{t} \mu_{t+1}+P_{t} \int_{0}^{1} \xi_{t}(v) d F(v) \\
P_{t}^{*} \mu_{t}^{*} & =\frac{\beta}{q_{t}} P_{t}^{*} \mathbb{E}_{t} \mu_{t+1}^{*}+P_{t}^{*} \int_{0}^{1} \xi_{t}^{*}(v) d F(v)
\end{aligned}
$$

3) Gross savings are allocated

$$
\begin{aligned}
a_{t+1} & =\frac{P_{t}}{q_{t}}\left(x_{t}-c_{t}\right) \\
a_{t+1}^{*} & =\frac{P_{t}^{*}}{q_{t}}\left(x_{t}^{*}-c_{t}^{*}\right)
\end{aligned}
$$

4) Optimal private debt choice

$$
\begin{aligned}
& q_{t} \mu_{t}=\beta \mathbb{E}_{t} \mu_{t+1}+q_{t} \lambda_{t} \\
& q_{t} \mu_{t}^{*}=\beta \mathbb{E}_{t} \mu_{t+1}^{*}+q_{t} \lambda_{t}^{*}
\end{aligned}
$$

5) Intermediate home goods markets demand

$$
\begin{gathered}
y_{t}^{H}=\kappa\left(\frac{P_{t}^{H}}{P_{t}}\right)^{-\sigma} y_{t} \\
y_{t}^{* H}=\left(1-\kappa^{*}\right)\left(\frac{P_{t}^{H}}{P_{t}^{*}}\right)^{-\sigma} y_{t}^{*}
\end{gathered}
$$


6) Intermediate foreign goods markets demand

$$
\begin{gathered}
y_{t}^{F}=(1-\kappa)\left(\frac{P_{t}^{F}}{P_{t}}\right)^{-\sigma} y_{t} \\
y_{t}^{* F}=\kappa^{*}\left(\frac{P_{t}^{F}}{P_{t}^{*}}\right)^{-\sigma} y_{t}^{*}
\end{gathered}
$$

7) Intermediate goods markets clear

$$
\begin{aligned}
& \tilde{y}_{t}=y_{t}^{H}+y_{t}^{H *} \\
& \tilde{y}_{t}^{*}=y_{t}^{F}+y_{t}^{* F}
\end{aligned}
$$

8) Intermediate goods market production

$$
\begin{gathered}
\tilde{y}_{t}=\xi_{z, t} k_{t-1}^{\omega} n_{t}^{1-\omega} \\
\tilde{y}_{t}^{*}=\xi_{z, t}^{*}\left(k_{t-1}^{*}\right)^{\omega}\left(n_{t}^{*}\right)^{1-\omega}
\end{gathered}
$$

9) Marginal product of capital

$$
\begin{gathered}
r_{t}=\omega\left(\frac{P_{t}^{H}}{P_{t}}\right) \xi_{z, t}\left(\frac{n_{t}}{k_{t-1}}\right) \\
r_{t}^{*}=\omega\left(\frac{P_{t}^{F}}{P_{t}^{*}}\right) \xi_{z, t}^{*}\left(\frac{n_{t}^{*}}{k_{t-1}^{*}}\right)^{1-\omega}
\end{gathered}
$$

10) Marginal product of labor

$$
\begin{aligned}
& w_{t}=(1-\omega)\left(\frac{P_{t}^{H}}{P_{t}}\right) \xi_{z, t}\left(\frac{n_{t}}{k_{t-1}}\right)^{-\omega} \\
& w_{t}^{*}=(1-\omega)\left(\frac{P_{t}^{F}}{P_{t}^{*}}\right) \xi_{z, t}^{*}\left(\frac{n_{t}^{*}}{k_{t-1}^{*}}\right)^{-\omega}
\end{aligned}
$$


11) Final goods price indices

$$
\begin{gathered}
P_{t}=\left[\kappa\left(P_{t}^{H}\right)^{1-\sigma}+(1-\kappa)\left(P_{t}^{F}\right)^{1-\sigma}\right]^{\frac{1}{1-\sigma}} \\
P_{t}^{*}=\left[\left(1-\kappa^{*}\right)\left(P_{t}^{H}\right)^{1-\sigma}+\kappa^{*}\left(P_{t}^{F}\right)^{1-\sigma}\right]^{\frac{1}{1-\sigma}}
\end{gathered}
$$

12) Final good market clearing condition

$$
\begin{gathered}
y_{t}=c_{t}+i_{t}+g_{t} \\
y_{t}^{*}=c_{t}^{*}+i_{t}^{*}+g_{t}^{*}
\end{gathered}
$$

13) Investment dynamics

$$
\begin{aligned}
& i_{t}=k_{t}-(1-\delta) k_{t-1}+\frac{\phi_{k}}{2} k_{t-1}\left(\frac{k_{t}}{k_{t-1}}-1\right)^{2} \\
& i_{t}^{*}=k_{t}^{*}-(1-\delta) k_{t-1}^{*}+\frac{\phi_{k}}{2} k_{t-1}^{*}\left(\frac{k_{t}^{*}}{k_{t-1}^{*}}-1\right)^{2}
\end{aligned}
$$

14) Household budget constraints are satisfied

$$
\begin{gathered}
P_{t} x_{t}+e_{t}\left(h_{t+1}-h_{t}\right)+P_{t} i_{t}=w_{t} n_{t}+q_{t} b_{t+1}-b_{t}+a_{t}+r_{k t} k_{t-1}-P_{t} t_{t}+b_{t}^{g}-\frac{1}{R_{t}} b_{t+1}^{g} \\
P_{t}^{*} x_{t}^{*}+e_{t}^{*}\left(h_{t+1}^{*}-h_{t}^{*}\right)+P_{t}^{*} i_{t}^{*}=w_{t}^{*} n_{t}^{*}+q_{t} b_{t+1}^{*}-b_{t}^{*}+a_{t}^{*}+r_{k t}^{*} k_{t-1}^{*}-P_{t}^{*} t_{t}^{*}+b_{t}^{g *}-\frac{1}{R_{t}^{*}} b_{t+1}^{g *}
\end{gathered}
$$

15) Housing choices are optimized

$$
\begin{gathered}
\lambda_{t} m_{t} e_{t}+\beta \eta^{h} \mathbb{E}_{t} \frac{1}{h_{t+1}}=\mu_{t} e_{t}-\beta \mathbb{E}_{t} e_{t+1} \mu_{t+1} \\
\lambda_{t}^{*} m_{t}^{*} e_{t}^{*}+\beta \eta^{h} \mathbb{E}_{t} \frac{1}{h_{t+1}^{*}}=\mu_{t}^{*} e_{t}^{*}-\beta \mathbb{E}_{t} e_{t+1}^{*} \mu_{t+1}^{*}
\end{gathered}
$$


16) Capital stock choices are optimized

$$
\begin{aligned}
P_{t} \mu_{t}+\phi_{k} P_{t} \mu_{t}\left(\frac{k_{t}}{k_{t-1}}-1\right) & =\beta \mathbb{E}_{t} \mu_{t+1}\left[P_{t+1}(1-\delta)+r_{k, t+1}\right]+\beta \frac{\phi_{k}}{2} \mathbb{E}_{t} P_{t+1} \mu_{t+1}\left(\frac{k_{t}^{2}}{k_{t-1}^{2}}-1\right) \\
P_{t}^{*} \mu_{t}^{*}+\phi_{k} P_{t}^{*} \mu_{t}^{*}\left(\frac{k_{t}^{*}}{k_{t-1}^{*}}-1\right) & =\beta \mathbb{E}_{t} \mu_{t+1}^{*}\left[P_{t+1}^{*}(1-\delta)+r_{k, t+1}^{*}\right]+\beta \frac{\phi_{k}}{2} \mathbb{E}_{t} P_{t+1}^{*} \mu_{t+1}^{*}\left(\frac{\left(k_{t}^{*}\right)^{2}}{\left(k_{t-1}^{*}\right)^{2}}-1\right)
\end{aligned}
$$

17) Housing markets clear

$$
\begin{aligned}
& h_{t+1}=1 \\
& h_{t+1}^{*}=1
\end{aligned}
$$

18) Borrowing constraints bind

$$
\begin{aligned}
& q_{t} b_{t+1}=m_{t} e_{t} h_{t+1} \\
& q_{t} b_{t+1}^{*}=m_{t}^{*} e_{t}^{*} h_{t+1}^{*}
\end{aligned}
$$

19) Optimal labor choices

$$
\begin{gathered}
n_{t}^{\nu}=w_{t} \mu_{t} \\
\left(n_{t}^{*}\right)^{\nu}=w_{t}^{*} \mu_{t}^{*}
\end{gathered}
$$

20) Optimal government debt choice

$$
\begin{aligned}
\frac{1}{R_{t}} \mu_{t} & =\beta \mathbb{E}_{t} \mu_{t+1} \\
\frac{1}{R_{t}^{*}} \mu_{t}^{*} & =\beta \mathbb{E}_{t} \mu_{t+1}^{*}
\end{aligned}
$$

21) Government budget constraints bind

$$
\frac{1}{R_{t}} b_{t+1}^{g}-b_{t}^{g}=P_{t} g_{t}-P_{t} t_{t}
$$




$$
\frac{1}{R_{t}^{*}} b_{t+1}^{g *}-b_{t}^{g *}=P_{t}^{*} g_{t}^{*}-P_{t}^{*} t_{t}^{*}
$$

22) Government spending rule

$$
\begin{gathered}
g_{t}=\frac{g}{y} y_{t}+\xi_{g, t} \\
g_{t}^{*}=\frac{g^{*}}{y^{*}} y_{t}^{*}+\xi_{g, t}^{*}
\end{gathered}
$$

23) Government lump-sum tax rule

$$
\begin{gathered}
\frac{t_{t}}{y_{t}}=\frac{t}{y}+\phi_{b}\left(\frac{b_{t+1}^{g}}{P_{t} y_{t}}-\frac{b^{g}}{P y}\right) \\
\frac{t_{t}^{*}}{y_{t}^{*}}=\frac{t^{*}}{y^{*}}+\phi_{b}^{*}\left(\frac{b_{t+1}^{g *}}{P_{t}^{*} y_{t}^{*}}-\frac{b^{g *}}{P^{*} y^{*}}\right)
\end{gathered}
$$

Note that the global asset market clearing condition is $b_{t}+b_{t}^{*}=a_{t}+a_{t}^{*}$ which follows from the household and government budget constraints, the optimal savings allocations, goods market clearing conditions, and housing market clearing conditions.

\section{B.1 Solution for Consumption}

To solve for consumption $c_{t}$, we have, from $c_{t}(v)=\min \left[\frac{v}{\frac{\beta}{q_{t}} P_{t} \mathbb{E}_{t} \mu_{t+1}}, x_{t}\right]$,

$$
c_{t}=\int_{0}^{\infty} c_{t}(v) f(v) d v=\int_{1}^{\bar{v}} \frac{v}{\frac{\beta}{q_{t}} P_{t} \mathbb{E}_{t} \mu_{t+1}} \alpha v^{-\alpha-1} d v+\int_{\bar{v}}^{\infty} x_{t} \alpha v^{-\alpha-1} d v
$$

and since $\bar{v}=\frac{x_{t}}{\frac{\beta}{q_{t}} P_{t} \mathbb{E}_{t} \mu_{t+1}}$, evaluating this expression gives

$$
\frac{c_{t}}{\underline{\mathrm{c}}_{t}}=\frac{\alpha}{\alpha-1}\left[1-\frac{1}{\alpha}\left(\frac{\underline{\mathrm{c}}_{t}}{x_{t}}\right)^{\alpha-1}\right]
$$


So we can substitute the expressions for consumption above with the ratio of consumption to minimum consumption and use the definitions for minimum consumption

$$
\underline{\mathrm{c}}_{t}=\frac{1}{\frac{\beta}{q_{t}} P_{t} \mathbb{E}_{t} \mu_{t+1}}
$$

\section{Additional Results on Macroprudential Rules}

\section{C.1 Welfare Function}

The household's utility function is

$$
U=\max \sum_{t=0}^{\infty} \beta^{t}\left(\int_{0}^{1} v_{i t} \log c_{i t} \mathrm{~d} i+\eta^{h} \log h_{t}-\frac{1}{1+\nu} n_{t}^{1+\nu}\right)
$$

which, integrating over the Pareto distribution and the solution for consumption, the first term can be written as

$$
\begin{aligned}
& \int_{0}^{1} v_{i t} \log c_{i t} \mathrm{~d} i=\frac{\alpha}{\alpha-1} \log \left(\underline{c}_{t}\right)\left(1-\bar{v}_{t}^{1-\alpha}\right)+ \\
& \frac{\alpha}{(\alpha-1)^{2}}\left[1-\bar{v}_{t}^{1-\alpha}\left(1+(\alpha-1) \log \bar{v}_{t}\right)\right]+\frac{\alpha}{\alpha-1} \log \left[x_{t}\right] \bar{v}_{t}^{1-\alpha},
\end{aligned}
$$

where $\bar{v}=\frac{x_{t}}{\frac{\beta}{q_{t}} P_{t} \mathbb{E}_{t} \mu_{t+1}}$. We can then write $U$ in recursive form.

\section{C.2 Welfare-Based Coefficients}

Figure C.1 shows plots of the welfare function under a second-order approximation over values of the $\phi_{m}$ weight in the candidate macroprudential rules. The left panel shows welfare over the macroprudential rule that responds to lagged debt shocks, while the right panel shows welfare over coefficients of the macroprudential rule that responds to house price deviations from steady-state. Under the debt-shock rule, welfare is maximized at $\phi_{m}=0.8$, while under the house price rule, welfare is maximized at $\phi_{m}=8.4$.

The optimal coefficient for the fiscal policy rule in the response to the growth rate of output 
Figure C.1: Optimal Macroprudential Rule Coefficients
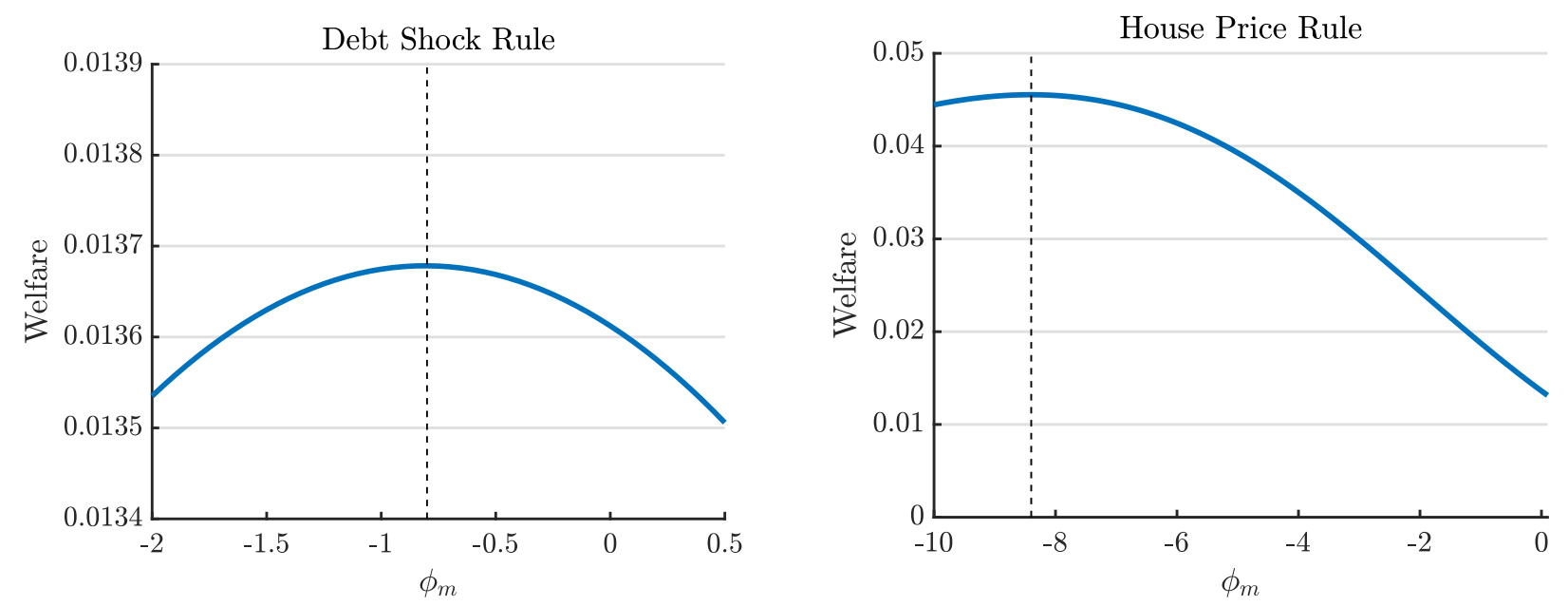

Figure C.2: Optimal Fiscal Rule Coefficients

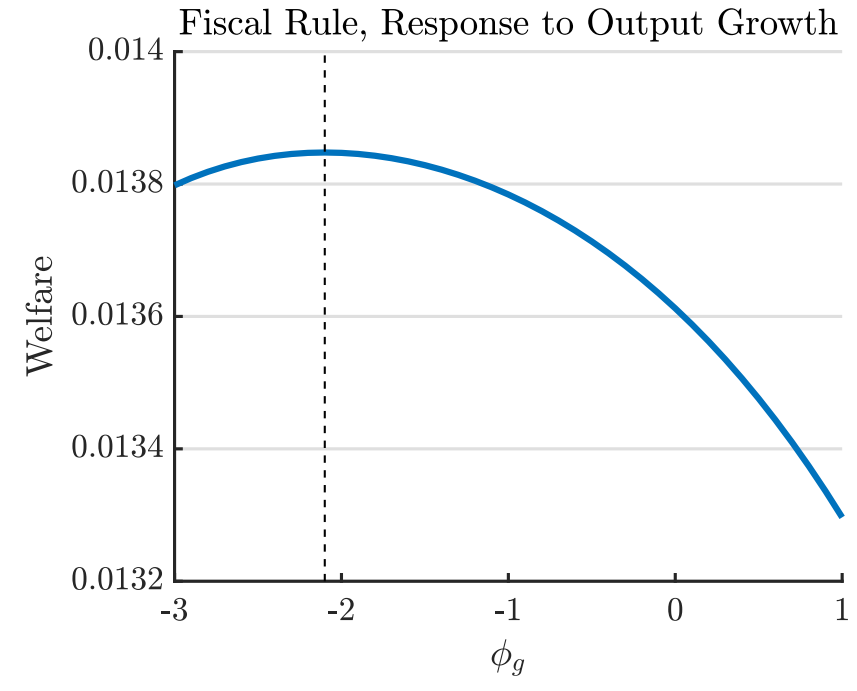

is shown in Figure C.2, with welfare maximized around a coefficient of $\phi_{g}=-0.7$.

\section{C.3 Macropru Rule Targeting House Prices at Optimal Coefficients}

Here, we present the counterfactual paths under the macroprudential rule targeting house prices, and with the coefficient $\phi_{m}=8.4$, in line with the optimal coefficients that maximize welfare under a second-order approximation.

$$
\text { macropru }_{t}=1-\phi_{m}\left(\frac{e_{t-1}}{e}-1\right) .
$$


Figure C.3: Macroprudential Rule Responding to House Price Fluctuations
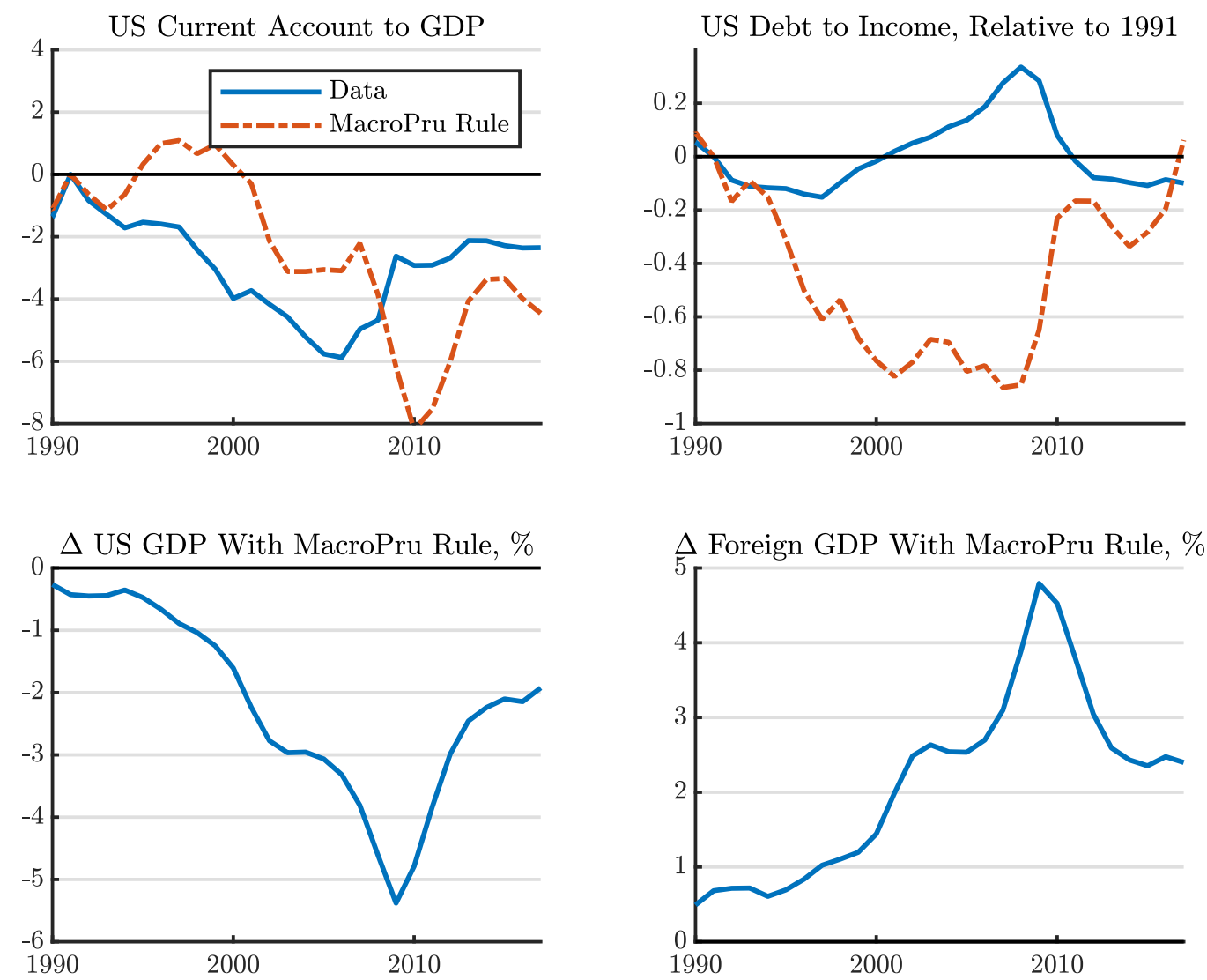

As shown in Figure C.3, the rule would generate a significantly flatter profile for debt-toincome, with debt-to-income falling between 1991 and 1997, and remaining around that level until 2009. During the period that debt contracts in the data, the macroprudential rule (C.1) with a coefficient of 8.4 would call for significantly looser credit, expanding household debt, and causing the current account-to-GDP ratio to fall by about 6 percentage points between 2007 and 2010. US output in this counterfactual would expand, helping to offset the recessionary shocks associated with the Great Recession. 